\title{
Synthesis and Characterization of Tc(I) Carbonyl Nitrosyl Species Relevant to the Hanford Tank Waste: FY 2016 Status Report
}

GB Hall

SD Chatterjee TG Levitskaia

TJ Martin

NA Wall

ED Walter

\section{November 2015}




\title{
DISCLAIMER
}

This report was prepared as an account of work sponsored by an agency of the United States Government. Neither the United States Government nor any agency thereof, nor Battelle Memorial Institute, nor any of their employees, makes any warranty, express or implied, or assumes any legal liability or responsibility for the accuracy, completeness, or usefulness of any information, apparatus, product, or process disclosed, or represents that its use would not infringe privately owned rights. Reference herein to any specific commercial product, process, or service by trade name, trademark, manufacturer, or otherwise does not necessarily constitute or imply its endorsement, recommendation, or favoring by the United States Government or any agency thereof, or Battelle Memorial Institute. The views and opinions of authors expressed herein do not necessarily state or reflect those of the United States Government or any agency thereof.

\author{
PACIFIC NORTHWEST NATIONAL LABORATORY \\ operated by \\ BATTELLE \\ for the \\ UNITED STATES DEPARTMENT OF ENERGY \\ under Contract DE-AC05-76RL01830 \\ Printed in the United States of America \\ Available to DOE and DOE contractors from the \\ Office of Scientific and Technical Information, \\ P.O. Box 62, Oak Ridge, TN 37831-0062; \\ ph: (865) 576-8401 \\ fax: (865) 576-5728 \\ email: reports $\_$adonis.osti.gov \\ Available to the public from the National Technical Information Service \\ 5301 Shawnee Rd., Alexandria, VA 22312 \\ ph: (800) 553-NTIS (6847) \\ email: $\operatorname{orders} a$ ntis.gov $<$ http://www.ntis.gov/about/form.aspx $>$ \\ Online ordering: http://www.ntis.gov
}

This document was printed on recycled paper.

(8/2010) 


\title{
Synthesis and Characterization of Tc(I) Carbonyl Nitrosyl Species Relevant to the Hanford Tank Waste: FY 2016 Status Report
}

\author{
GB Hall \\ SD Chatterjee \\ TG Levitskaia \\ T Martin \\ NA Wall \\ ED Walter
}

November 2015

Prepared for

the U.S. Department of Energy

under Contract DE-AC05-76RL01830

Pacific Northwest National Laboratory

Richland, Washington 99352 



\section{Summary}

Among long-lived radioactive constituents in the Hanford tank waste, Tc presents a unique challenge in that it exists predominantly in the liquid phase, generally in the anionic form of pertechnetate, $\mathrm{TcO}_{4}^{-}$, which is highly volatile at low-activity waste (LAW) vitrification melter temperatures and mobile in the Hanford site's subsurface environment. The complex behavior of Tc under storage, treatment, and immobilization conditions significantly affects its management options, which to-date remain uncertain.

In strongly alkaline environments, $\mathrm{Tc}$ exists as pertechnetate, $\mathrm{TcO}_{4}{ }^{-}$(oxidation state +7 ), and in the reduced forms (oxidation state $<+7$ ) collectively known as non-pertechnetate species. Pertechnetate is a well-characterized, anionic Tc species that can be removed from LAW by anion exchange or solvent extraction methods. There is no definitive information on the origin of the non-pertechnetate Tc species, nor is there a comprehensive description of their composition and behavior. It has been recently proposed that the non-pertechnetate species can comprise Tc(I) metal center and carbonyl or mixed carbonyl nitrosyl ligands stabilizing low-valent Tc. Recent work by our group has significantly expanded this previous work, generating a series of Tc(I) carbonyl compounds and demonstrating that they can be generated from reduction of $\mathrm{TcO}_{4}{ }^{-}$in the simulated Hanford tank waste in presence of $\mathrm{CO}$ at elevated temperature (Levitskaia et al. 2014). These results are consistent with the previous proposal that $\left[\mathrm{Tc}(\mathrm{CO})_{3}\right]^{+}$species can be present in the Hanford tank waste and suggest that the low $\mathrm{Tc}(\mathrm{I})$ oxidation state is stabilized by the $\pi$-accepting ability of the CO ligands. The continuation work has been initiated to develop model Tc carbonyl nitrosyl compounds and investigate their potential presence in the Hanford tank wastes. This report summarizes our to-date results.

Synthesis of the low-valent Tc carbonyl nitrosyl complexes was performed using two Tc(I) tricarbonyl precursors, namely monomeric $\left[\mathrm{Tc}(\mathrm{CO})_{3} \mathrm{Cl}_{3}\right]^{2-}$ and tetrameric $\left[\mathrm{Tc}(\mathrm{CO})_{3}(\mathrm{OH})\right]_{4}$ species, in methylene chloride solvent using $\mathrm{NOBF}_{4}$ as the nitrolysation reagent. Both pathways generated $\left[\mathrm{Tc}(\mathrm{CO})_{2}(\mathrm{NO})\right]^{2+}$ species as evident from the Tc-99 nuclear magnetic resonance (NMR) and infrared (IR) spectroscopic characterization of the reaction products. The reaction yield using $\left[\mathrm{Tc}(\mathrm{CO})_{3} \mathrm{Cl}_{3}\right]^{2-}$ starting material was about $70 \%$ with the Tc carbonyl nitrosyl species partitioned between the liquid and solid reaction fractions, and about $30 \%$ of starting $\mathrm{Tc}(\mathrm{I})$ oxidized to $\mathrm{Tc}(\mathrm{VII})$. The reaction yield using $\left[\mathrm{Tc}(\mathrm{CO})_{3}(\mathrm{OH})\right]_{4}$ starting material was nearly quantitative with Tc carbonyl nitrosyl product forming insoluble precipitate.

The obtained results suggest that the Tc carbonyl nitrosyl product contained one monomeric $\left[\mathrm{Tc}(\mathrm{CO})_{2}(\mathrm{NO}) \mathrm{Cl}_{3}\right]^{-}$and two trans Cl-bridged dimeric $\left[\mathrm{Tc}(\mathrm{CO})_{2}(\mathrm{NO})(\mu-\mathrm{Cl}) \mathrm{Cl}\right]_{2}$ species. However, this assignment should be validated by the future studies. Density functional theory (DFT) computational modeling supported the spectroscopic characterization of the Tc carbonyl nitrosyl products and helped in assignment of the observed signals. The dissolution of the obtained Tc(I) carbonyl nitrosyl product in water and aqueous $5 \mathrm{M} \mathrm{NaNO}_{3}$ solution was accompanied by conversion of $\mathrm{Tc}$ (I) to $\mathrm{Tc}$ (II) demonstrated using electron paramagnetic resonance (EPR) spectroscopy. The resulting solutions showed no oxidation to $\mathrm{Tc}$ (VII) for up to 30 days, and their monitoring is currently continuing. These preliminary results suggest that the low-valent Tc carbonyl nitrosyl exhibits similar or greater stability/resistance to oxidation than the $\mathrm{Tc}(\mathrm{I})\left[\mathrm{Tc}(\mathrm{CO})_{3}\right]^{+}$species, and further testing in the solutions simulating Hanford tank supernatants is warranted. 



\section{Acknowledgements}

This work was completed as part of the Technetium Management Hanford Site project. Support for this project came from the U.S. Department of Energy's Office of Environmental Management. We would like to especially acknowledge the support of Dr. Nicholas Machara.

The authors would like to thank RJ Serne for his technical review. 



\section{Acronyms and Abbreviations}

$\begin{array}{ll}\text { ATR } & \text { attenuated total reflectance } \\ \text { DFT } & \text { density functional theory } \\ \text { DIW } & \text { deionized water } \\ \text { DST } & \text { double-shell tank } \\ \text { EPR } & \text { electron paramagnetic resonance } \\ \text { FY } & \text { fiscal year } \\ \text { IR } & \text { infrared } \\ \text { LAW } & \text { low-activity waste } \\ \text { LSC } & \text { liquid scintillation counting } \\ \text { NMR } & \text { nuclear magnetic resonance } \\ \text { PNNL } & \text { Pacific Northwest National Laboratory } \\ \text { QA } & \text { quality assurance } \\ \text { RPL } & \text { Radiochemical Processing Laboratory } \\ \text { SST } & \text { single-shell tank }\end{array}$





\section{Contents}

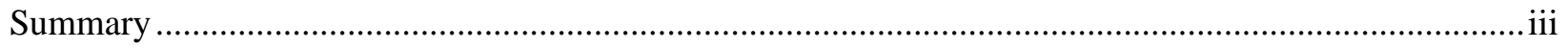

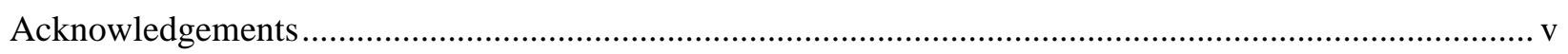

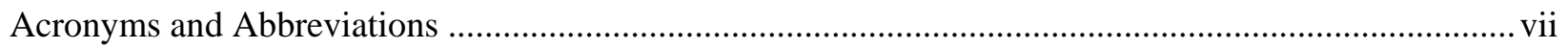

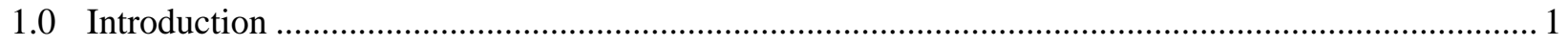

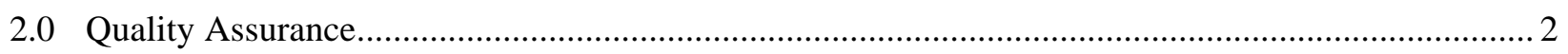

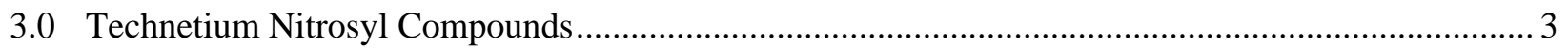

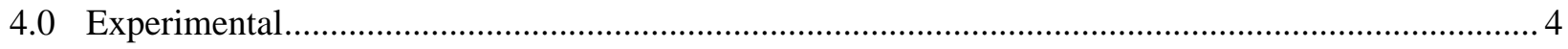

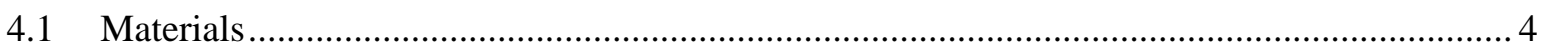

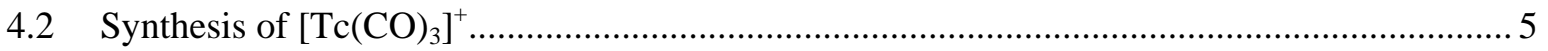

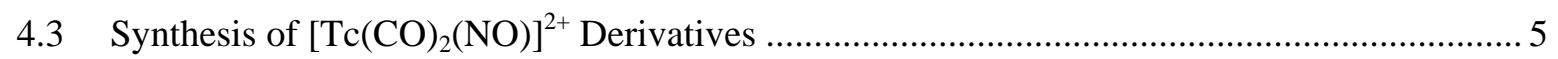

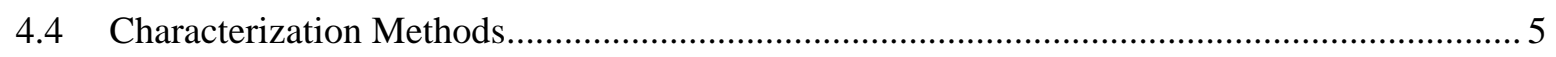

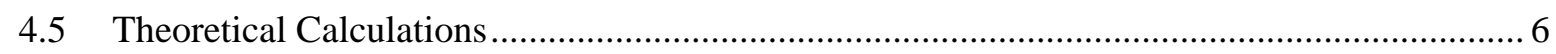

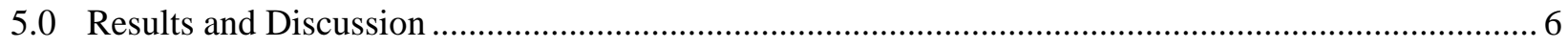

5.1 Characterization of the $\left[\mathrm{Tc}(\mathrm{CO})_{2}(\mathrm{NO})\right]^{2+}$ Products Obtained Using

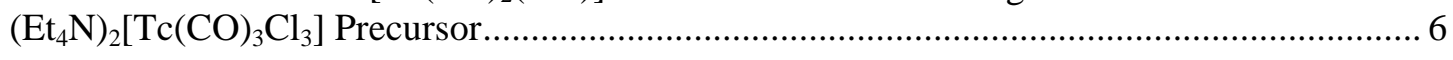

5.1.1 Characterization of the $\left[\mathrm{Tc}(\mathrm{CO})_{2}(\mathrm{NO})\right]^{2+}$ Products in the Reaction

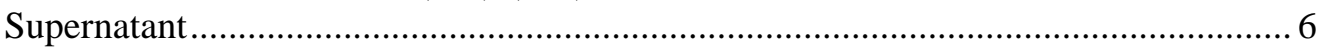

5.1.2 Characterization of the $\left[\mathrm{Tc}(\mathrm{CO})_{2}(\mathrm{NO})\right]^{2+}$ Products in the Reaction Solid

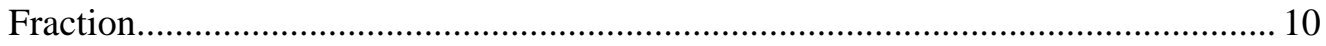

5.2 Characterization of the $\left[\mathrm{Tc}(\mathrm{CO})_{2}(\mathrm{NO})\right]^{2+}$ Products Obtained Using $\left[\mathrm{Tc}(\mathrm{CO})_{3} \mathrm{OH}\right]_{4}$

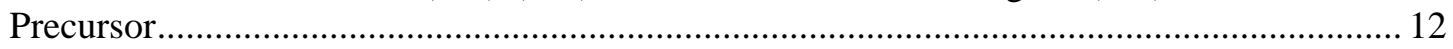

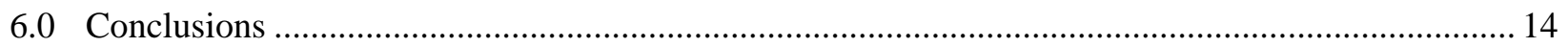

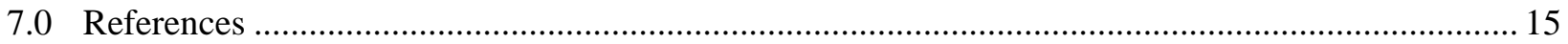




\section{Figures}

1. Technetium-99 NMR Spectrum of the $\mathrm{CH}_{2} \mathrm{Cl}_{2}$ Supernatant Obtained by the Reaction of $\left[\mathrm{Tc}(\mathrm{CO})_{3} \mathrm{Cl}_{3}\right]^{2-}$ with $\mathrm{NOBF}_{4}$

2. Molecular Structures of the Proposed Cl-bridged Dimeric $\left[\mathrm{Tc}(\mathrm{CO})_{2}(\mathrm{NO})\right]^{2+}$-based Species

Formed by the Mononitrosylation of the Tc Carbonyl Centers

3. Infrared Spectra of the Supernatant $\mathrm{CH}_{2} \mathrm{Cl}_{2}$ Solution and the Solid Precipitate Obtained by the Reaction of $\left[\mathrm{Tc}(\mathrm{CO})_{3} \mathrm{Cl}_{3}\right]^{2-}$ with $\mathrm{NOBF}_{4}$

4. Technetium-99 NMR Spectrum of the Precipitate Obtained from the Reaction of $\left[\mathrm{Tc}(\mathrm{CO})_{3} \mathrm{Cl}_{3}\right]^{2-}$ with $\mathrm{NOBF}_{4}$ and Dissolved in $\mathrm{EtOH}$.

5. Technetium-99 NMR Spectra of the Precipitate Obtained by the Reaction of $\left[\mathrm{Tc}(\mathrm{CO})_{3} \mathrm{Cl}_{3}\right]^{2-}$ with $\mathrm{NOBF}_{4}$ Dissolved in Water and Recorded at $\mathrm{t}=30$ Minutes and at $\mathrm{t}=30$ Days or Dissolved in Aqueous $5 \mathrm{M} \mathrm{NaNO}_{3}$ Solution and Recorded at $\mathrm{t}=30$ Minutes and at $\mathrm{t}=3$ Days After Sample Preparation

6. Technetium-99 EPR Spectrum of the Aqueous Solution of the Precipitate Obtained from the Reaction of $\left[\mathrm{Tc}(\mathrm{CO})_{3} \mathrm{Cl}_{3}\right]^{2-}$ with $\mathrm{NOBF}_{4}$

7. Technetium-99 NMR Spectra in Diethyl Ether of the Precipitate Obtained by the Reaction of $\left[\mathrm{Tc}(\mathrm{CO})_{3}(\mathrm{OH})\right]_{4}$ with $\mathrm{NOBF}_{4}$ Recorded at 30 min and 30 Days After Sample Preparation

8. Technetium-99 NMR Spectra in Acetonitrile Solution of the Precipitate Obtained by the Reaction of $\left[\mathrm{Tc}(\mathrm{CO})_{3}(\mathrm{OH})\right]_{4}$ with $\mathrm{NOBF}_{4}$ Recorded at 30 min and 3 Days After Sample Preparation

9. Technetium-99 NMR Spectra of the Precipitate Obtained by the Reaction of $\left[\mathrm{Tc}(\mathrm{CO})_{3}(\mathrm{OH})\right]_{4}$ with $\mathrm{NOBF}_{4}$ Dissolved in Water and Recorded at $\mathrm{t}=30$ Minutes and at $\mathrm{t}=30$ Days or Dissolved in Aqueous $5 \mathrm{M} \mathrm{NaNO}_{3}$ Solution and Recorded at $\mathrm{t}=30$ Minutes and at $\mathrm{t}=7$ Days After Sample Preparation.

\section{Tables}

1. Techetium-99 NMR Characterization of the $\mathrm{CH}_{2} \mathrm{Cl}_{2}$ Supernatant Solution Obtained by the Reaction of $\left[\mathrm{Tc}(\mathrm{CO})_{3} \mathrm{Cl}_{3}\right]^{2-}$ with $\mathrm{NOBF}_{4}$

2. Techetium-99 NMR Characterization of the Precipitate Obtained by the Reaction of $\left[\mathrm{Tc}(\mathrm{CO})_{3} \mathrm{Cl}_{3}\right]^{2-}$ with $\mathrm{NOBF}_{4}$ Dissolved in $\mathrm{EtOH}$ 


\subsection{Introduction}

As described in TP-EMSP-0018 ${ }^{1}$, Technetuim-99 (Tc) generated from the fission of ${ }^{235} \mathrm{U}$ and ${ }^{239} \mathrm{Pu}$ in high yields is a Hanford Nuclear Reservation tank waste constituent. Among radioactive constituents in the tank waste, Tc presents a unique challenge in that it has a long half-life $(\beta=292 \mathrm{keV}$; $\mathrm{T}_{1 / 2}=2.11 \times 10^{5} \mathrm{y}$ ) and exists predominantly in the liquid phase, generally in the anionic form of pertechnetate, $\mathrm{TcO}_{4}{ }^{-}$, which is highly volatile at low-activity waste (LAW) vitrification melter temperatures and mobile in the Hanford site's subsurface environment. This makes immobilization of Tc into high-durability waste forms a critical technical challenge for nuclear waste management. The complex behavior of Tc under storage, treatment, and immobilization conditions significantly affects its management options, which to-date remain uncertain.

To address the management challenges associated with the treatment, immobilization, and disposal of technetium in tank wastes, this project examines a number of technical challenges, including separation, disposition, and detection. A test plan describing a scope of study in fiscal year (FY) 2015 designed to address these technical challenges has been prepared (TP-EMSP-0018). This test plan breaks down the scope of study into seven tasks; Task 3 is to study Tc redox speciation and identify options for treatment and removal from LAW Hanford tank waste supernatants.

Soluble Tc in the saltcake and supernatant fractions of both single-shell tanks (SSTs) and double-shell tanks (DSTs) constitutes most of the Tc at the Hanford Site. The DSTs contain $57 \%\left(1.51 \times 10^{4} \mathrm{Ci}\right)$ of the total Tc inventory $\left(2.65 \times 10^{4} \mathrm{Ci}\right)$ in Hanford tanks, with the bulk $\left(1.33 \times 10^{4} \mathrm{Ci}\right)$ being in four DST farms (AP, AN, AW, and AZ) in the 200-E Area (Serne et al. 2014). In strongly alkaline environments, Tc exists as pertechnetate, $\mathrm{TcO}_{4}{ }^{-}$(oxidation state +7 ), and in the reduced forms (oxidation state $<+7$ ) collectively known as non-pertechnetate species. Pertechnetate is a well-characterized, anionic Tc species that can be removed from LAW by anion exchange or solvent extraction methods. There is no definitive information on the origin of the non-pertechnetate Tc species, nor is there a comprehensive description of their composition and behavior.

It was recently proposed based on the x-ray absorption studies of the actual SY-101 and SY-103 tank waste supernatants that non-pertechnetate species are the derivatives of low-valent $\mathrm{Tc}(\mathrm{I})$ carbonyl moiety and derived from $f a c-\left[\mathrm{Tc}(\mathrm{CO})_{3}\right]^{+},{ }^{2}$ (Lukens et al. 2004). Recent work by our group has significantly expanded this hypothesis, demonstrating that Tc(I) carbonyl compounds can be generated from reduction of $\mathrm{TcO}_{4}{ }^{-}$in simulated Hanford tank waste in the presence $\mathrm{CO}$ at elevated temperature (Levitskaia et al. 2014), and ongoing monitoring of these samples indicates long-term stability of Tc(I) carbonyl non-pertechnetate ${ }^{3}$. These results are consistent with the proposal that $\left[\mathrm{Tc}(\mathrm{CO})_{3}\right]^{+}$species can be present in the Hanford tank waste and suggest that the low Tc(I) oxidation state is stabilized by the $\pi$-accepting ability of the CO ligands. It is also possible that other ligands with similar electronic structure and

\footnotetext{
${ }^{1}$ Levitskaia TG and DJ McCabe. 2015. Technetium Management-Hanford Site (FY 2015). TP-EMSP-0018 Rev.1.0, Pacific Northwest National Laboratory, Richland, WA.

${ }^{2}$ All Tc(I) carbonyl compounds described in this report have facial octahedral geometry, and in the following text notation " $f a c-$ " is omitted for clarity.

${ }^{3}$ These results are outside of the subject of this report and will be summarized in a separate report of Task 3 of the Technetium Management Program.
} 
geometry coordinate to Tc and stabilize its low oxidation states. Coordination of isolobal ${ }^{4}$ nitrosyl $\mathrm{NO}^{+}$ ligand to $\mathrm{Tc}$ and formation of $\left[\mathrm{Tc}(\mathrm{CO})_{2}(\mathrm{NO})\right]^{2+}$ compounds in the tank waste environment is an intriguing possibility because of reducing radicals generated during radiolysis of nitrate (Cook et al. 2001). This makes the generation of $\mathrm{NO}^{+}$coordinated $\mathrm{Tc}(\mathrm{I})$ dicarbonyl nitrosyl species $\left[\mathrm{Tc}(\mathrm{CO})_{2}(\mathrm{NO})\right]^{2+}$ and formation of their congeners a distinct possibility. To this regard, a literature review report "Technetium Inventory, Distribution, and Speciation in Hanford Tanks" (Serne et al. 2014) states that based on all investigations and detailed measurements, non-pertechnetate species in the Hanford DST supernates are tentatively identified as $\mathrm{Tc}(\mathrm{I})$ carbonyl complexes derived from either $\left[\mathrm{Tc}(\mathrm{CO})_{3}\right]^{+}$or $\left[\mathrm{Tc}(\mathrm{CO})_{2}(\mathrm{NO})\right]^{2+}$ precursor molecules that may lead to final species such as $\left[\mathrm{Tc}(\mathrm{CO})_{3}\right]^{+} \cdot$ gluconate as a result of the radiolytic decomposition of organics and nitrite in the DSTs.

The linear-coordinated $\mathrm{NO}^{+}$ligand is considered to be a better $\pi$-acceptor than the isoelectronic $\mathrm{CO}$ ligand, resulting in greater substitution lability of ligands in position trans to $\mathrm{NO}^{+}$as an overall effect. However, very little information on the properties of the $\left[\mathrm{Tc}(\mathrm{CO})_{2}(\mathrm{NO})\right]^{2+}$ compounds is available in the literature. Exploratory testing aimed at developing protocols to synthesize these compounds, and investigation of the hydrolysis mechanism, complexation properties, and redox stability of the $\left[\mathrm{Tc}(\mathrm{CO})_{2}(\mathrm{NO})\right]^{2+}$ compounds under conditions simulating Hanford supernatants, are planned under Task 3 of the Technetium Management Program ${ }^{1}$. This report responds to this Task 3 scope and summarizes relevant FY 2015 results.

\subsection{Quality Assurance}

This work was conducted as part of Pacific Northwest National Laboratory (PNNL) Project 54042 under the Technetium Management Program, with funding from the U.S. Department of Energy Office of Environmental Management.

All research and development (R\&D) work at PNNL is performed in accordance with PNNL's laboratory-level Quality Management Program, which is based on a graded application of NQA-1-2000, Quality Assurance Requirements for Nuclear Facility Applications, to R\&D activities. In addition to the PNNL-wide quality assurance (QA) controls, the QA controls of the WRPS Waste Form Testing Program (WWFTP) QA program were also implemented for the work. The WWFTP QA program consists of the WWFTP Quality Assurance Plan (QA-WWFTP-001) and associated QA-NSLW-numbered procedures that provide detailed instructions for implementing NQA-1 requirements for R\&D work. The WWFTP QA program is based on the requirements of NQA-1-2008, Quality Assurance Requirements for Nuclear Facility Applications, and NQA-1a-2009, Addenda to ASME NQA-1-2008 Quality Assurance Requirements for Nuclear Facility Applications, graded on the approach presented in NQA-1-2008, Part IV, Subpart 4.2, "Guidance on Graded Application of Quality Assurance (QA) for Nuclear-Related Research and Development". Preparation of this report and performance of the associated experimental work were assigned the technology level "Applied Research" and were conducted in accordance with procedure QA-NSLW-1102, Scientific Investigation for Applied Research. All staff members contributing to the work have technical expertise in the subject matter and received QA training prior to performing quality-affecting work. The "Applied Research" technology level provides adequate controls

\footnotetext{
${ }^{4}$ Two fragments are isolobal if the number, symmetry properties, approximate energy, and shape of the frontier orbitals and the number of electrons in them are similar.
} 
to ensure that the activities were performed correctly. Use of both the PNNL-wide and WWFTP QA controls ensured that all client QA expectations were addressed in performing the work.

\subsection{Technetium Nitrosyl Compounds}

There are only a few $\mathrm{NO}^{+}$-coordinated Tc complexes reported in literature; in addition to the $\mathrm{Tc}(\mathrm{I})$ $\left[\mathrm{Tc}(\mathrm{CO})_{2}(\mathrm{NO})\right]^{2+}$ complexes described in the following paragraph, there are few examples of the coordination of $\mathrm{NO}^{+}$to Tc resulting in the stabilization of $\mathrm{Tc}(\mathrm{I}), \mathrm{Tc}(\mathrm{II})$, and $\mathrm{Tc}(\mathrm{III})$ oxidation states without complexation of CO (Nicholson et al. 2006; Gong et al. 2008; Lu and Clarke 1992; de Vries et al. 1990; Raynor et al. 1992; Tisato et al. 1994). The preparation of the first Tc nitrosyl complex dates back to 1963 (Eakins et al. 1963), however they were characterized more than decade later, in 1976 (Armstrong and Taube 1976). Subsequently, a convenient high-yield synthetic route to the versatile $\mathrm{Tc}(\mathrm{II})$-containing material $\left[\mathrm{n}-\mathrm{Bu}_{4} \mathrm{~N}\right]\left[\mathrm{Tc}(\mathrm{NO}) \mathrm{Cl}_{4}\right]$ was reported (Cheah et al. 1987), prompting renewed interest in low-valent Tc-nitrosyl chemistry. Anionic Tc(II) species [ $\left.\mathrm{Tc}(\mathrm{NO}) \mathrm{Cl}_{4}(\mathrm{MeOH})\right]^{-}$(Brown et al. 1987) and $\left[\mathrm{Tc}(\mathrm{NO}) \mathrm{Cl}_{4}(\mathrm{acac})\right]^{-}$(where acac is acetylacetone) (Brown et al. 1988) as well as neutral $\left[\mathrm{Tc}(\mathrm{NO}) \mathrm{Br}_{2}\left(\mathrm{CN}^{t} \mathrm{bu}\right)_{3}\right]$ (where bu is tert-butyl) (Linder et al. 1986) complexes with distorted octahedral geometry were reported, suggesting the ability of the $\mathrm{NO}^{+}$ligand to stabilize the low-valent $\mathrm{Tc}(\mathrm{II})$ centers through $\pi$-back bonding leading to the delocalization of the Tc electron density. Similarly, stability of the $\mathrm{Tc}(\mathrm{III})$ complex $\left[\mathrm{Tc}(\mathrm{NO})\left(\mathrm{NH}_{3}\right)(\text { phen })_{2}\right]^{2+}$ (where phen is 1,10-phenanthroline) has also been attributed to the $\pi$-back-donation to the phenanthroline and $\mathrm{NO}^{+}$ligands (Lu and Clarke 1992). Recently, Nicholson (Nicholson et al. 2006) reported preparation of the Tc(I) complex $\left[\mathrm{TcCl}(\mathrm{NO})(\mathrm{dppe})_{2}\right]\left(\mathrm{PF}_{6}\right) \cdot \mathrm{CH}_{2} \mathrm{Cl}_{2}$ through the reductive nitrosylation of ammonium pertechnetate, $\mathrm{NH}_{4} \mathrm{TcO}_{4}$, using the reducing agent hydroxylamine, $\mathrm{NONH}_{2}$, followed by complexation with the bidentate ligand diphenylphosphinoethane (dppe), suggesting the ability of the $\mathrm{NO}^{+}$ligand to stabilize the low-valent $\mathrm{Tc}(\mathrm{I})$ center in combination with the $\pi$-accepting diphenylphosphine groups.

Chemistry of Tc(I) nitrosyl complexes has been expanded to the species derived from the $\left[\mathrm{Tc}(\mathrm{CO})_{2}(\mathrm{NO})\right]^{2+}$ moiety primarily in relationship to radiopharmaceutical applications (Rattat et al. 2001; Rattat et al. 2004; Yang et al. 2007). Rattat (Rattat et al. 2001) reported synthesis of $\left[\mathrm{Tc}(\mathrm{CO})_{2}(\mathrm{NO}) \mathrm{X}_{3}\right]^{-}$ by the reaction of the $\left[\mathrm{Tc}(\mathrm{CO})_{3} \mathrm{X}_{3}\right]^{2-}$ (where $\mathrm{X}$ is a halide) parent material with $\mathrm{NO}^{+} \mathrm{BF}_{4}{ }^{-}$in organic medium (e.g., methylene chloride, $\mathrm{CH}_{2} \mathrm{Cl}_{2}$ ). Similar substitution of $\mathrm{CO}$ by $\mathrm{NO}^{+}$was also achieved when $\left[\mathrm{Tc}(\mathrm{CO})_{3}(\mathrm{~L} \cap \mathrm{L} \cap \mathrm{L})\right]^{\mathrm{n}-}($ where $\mathrm{L} \cap \mathrm{L} \cap \mathrm{L}$ is nitrilotriacetic or iminodiacetic acid) were used as the starting complex (Rattat et al. 2004) in the organic solvent. In the chlorinated solvent, $\mathrm{NO}^{+} \mathrm{BF}_{4}^{-}$dissotiates and generates $\mathrm{NO}^{+}$directly. A different mechanism is proposed for the reaction in an aqueous medium. In aqueous solvents, it is hypothesized that $\mathrm{NO}^{+} \mathrm{BF}_{4}{ }^{-}$hydrolyzes to produce nitrous acid, $\mathrm{HNO}_{2}$, which in acidic, oxygen-free solution dissociates to provide $\mathrm{NO}^{+}$, and in an excess of $\mathrm{HCl}\left[\mathrm{Tc}(\mathrm{CO})_{3} \mathrm{X}_{3}\right]^{2-}$ is converted to $\left[\mathrm{Tc}(\mathrm{CO})_{2}(\mathrm{NO}) \mathrm{X}_{3}\right]^{-}$with $>99 \%$ yield (Yang et al. 2007). However, in these studies, elucidation of the molecular and electronic structure of the $\left[\mathrm{Tc}(\mathrm{CO})_{2}(\mathrm{NO})\right]^{2+}$ species is lacking.

The most detailed studies of the molecular structure of $\left[\mathrm{Tc}(\mathrm{CO})_{2}(\mathrm{NO})\right]^{2+}$ species was done by Schilbi and coworkers (Schibli et al. 2005), who reported the formation of the monomeric $\left[\mathrm{Tc}(\mathrm{CO})_{2}(\mathrm{NO})\right]^{2+}$ containing species $\left(\mathrm{NEt}_{4}\right)\left[\mathrm{Tc}(\mathrm{CO})_{2}(\mathrm{NO}) \mathrm{Cl}_{3}\right]$ and its dichloride bridged dimeric analog $\left[\mathrm{Tc}(\mathrm{CO})_{2}(\mathrm{NO})(\mu-\mathrm{Cl}) \mathrm{Cl}\right]_{2}$ through the nitrosylation of the $\left(\mathrm{NEt}_{4}\right)_{2}\left[\mathrm{Tc}(\mathrm{CO})_{3} \mathrm{Cl}_{3}\right]$ complex. However, the studies were mostly conducted in organic media, and the structure of these and related species in the aqueous media remains unexplored. 
The complex aqueous chemistry of $\left[\mathrm{Tc}(\mathrm{CO})_{2}(\mathrm{NO})\right]^{2+}$ can be anticipated based on the experimental data of rhenium (Re) analogs. Kurz et al. (2005) demonstrated the unusual and highly pH-dependent behavior of the $\left[\operatorname{Re}(\mathrm{CO})_{2}(\mathrm{NO})\right]^{2+}$ species as shown in Scheme 1. The $\left[\operatorname{Re}(\mathrm{CO})_{2}(\mathrm{NO})\left(\mathrm{H}_{2} \mathrm{O}\right)_{3}\right]^{2+}$ complex was observed to form the tetrameric $\left[\operatorname{Re}\left(\mu_{3}-\mathrm{O}\right)(\mathrm{CO})_{2}(\mathrm{NO})\right]_{4}$ cluster at $\mathrm{pH} 2-6$ when solution $\mathrm{pH}$ was increased slowly. Fast $\mathrm{pH}$ increase resulted in the dimeric $\left[\mathrm{Re}(\mathrm{CO})_{2}(\mathrm{NO})(\mathrm{OH})\left(\mathrm{H}_{2} \mathrm{O}\right)_{2}\right]_{2}{ }^{2+}$ complex up to $\mathrm{pH}$ of 10 . Further $\mathrm{pH}$ increase generated a tetrameric $[\mathrm{ReC}(\mathrm{O}) \mathrm{O}(\mathrm{NO})]_{4}$ species. It is likely that the aqueous chemistry of $\left[\mathrm{Tc}(\mathrm{CO})_{2}(\mathrm{NO})\right]^{2+}$ can show similar dependence on $\mathrm{pH}$.
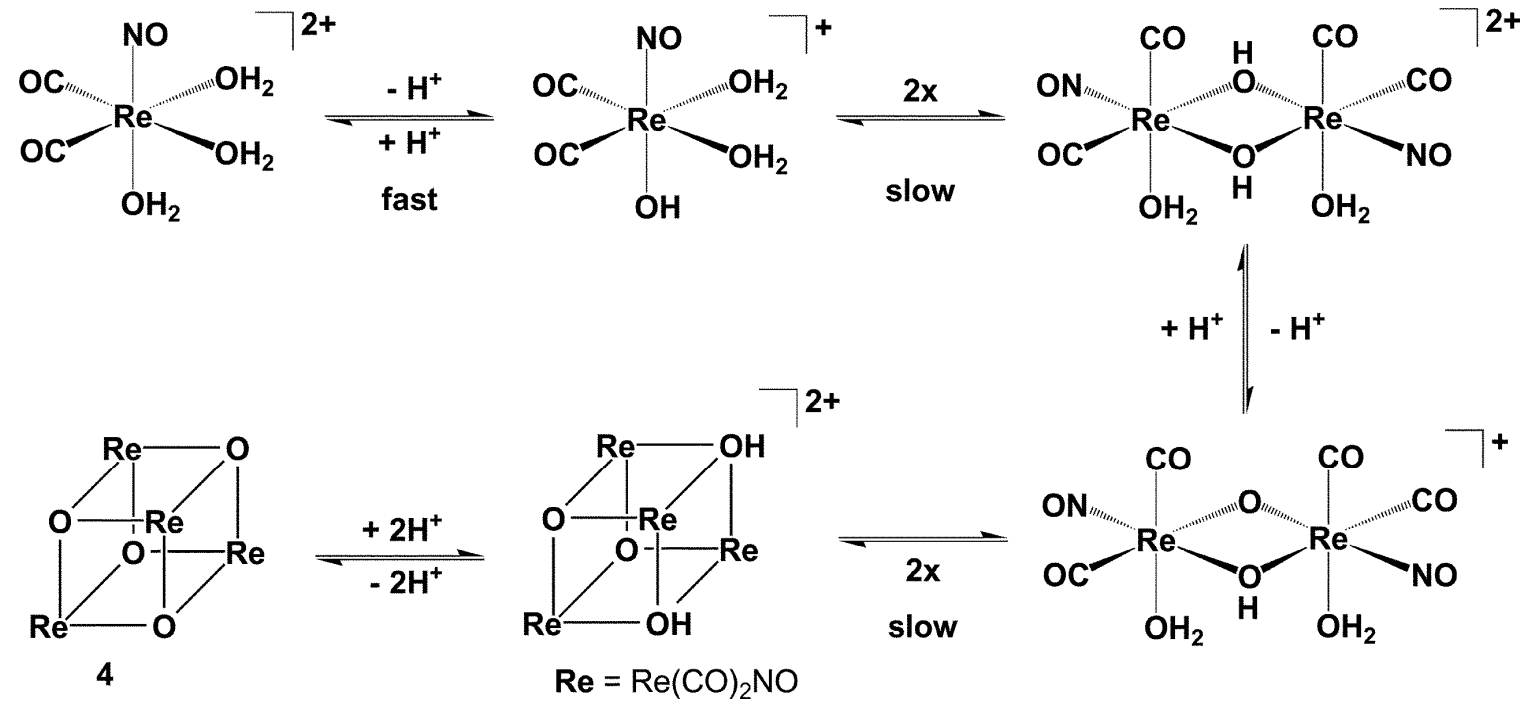

Scheme 1. Speciation Pathway of $\left[\operatorname{Re}(\mathrm{CO})_{2}(\mathrm{NO})\right]^{2+}$ as a Function of $\mathrm{pH}$

One characteristic of the $\left[\mathrm{Tc}(\mathrm{CO})_{3}\right]^{+}$moiety is the presence of a 'soft' metal center according to the definition of Pearson (Pearson 1963). The nitrosyl ligand, $\mathrm{NO}^{+}$, is isoelectronic with $\mathrm{CO}$, but is a better $\pi$-acceptor and thus better stabilizer of the $\pi$-donating ligands in the trans-position. Replacing one of the three carbonyls in the $\left[\mathrm{Tc}(\mathrm{CO})_{3}\right]^{+}$core moiety by a less $\sigma$-donating and more $\pi$-accepting nitrosyl group significantly changes chemical and physical properties of the complex. According to Pearson's concept of hard and soft acids and bases, the nitrosyl-coordinated metal center becomes harder and acquires a preference for reaction partners like oxo- or nitrogen-groups (Pearson 1963, 1968a, 1968b). In addition, a nitrosyl ligand, as opposed to a carbonyl ligand, causes a bigger split of the HOMO-LUMO gap, thus increasing the stability of the complex $(\mathrm{HOMO}=$ highest occupied molecular orbital; LUMO = lowest unoccupied molecular orbital).

\subsection{Experimental}

\subsection{Materials}

In-house $\mathrm{NH}_{4} \mathrm{TcO}_{4}$ stock available at the Radiochemical Processing Laboratory (RPL) at PNNL was used. Diglyme (bis(2-methoxyethyl)ether), acetonitrile $(\mathrm{MeCN})$, diethyl ether $\left(\mathrm{Et}_{2} \mathrm{O}\right)$, ethanol $(\mathrm{EtOH})$, dichloromethane $\left(\mathrm{CH}_{2} \mathrm{Cl}_{2}\right)$, tetrahydrofuran (THF), and borane-tetrahydrofuran $\left(\mathrm{BH}_{3} / \mathrm{THF}\right.$ complex $)$ were obtained from Sigma-Aldrich and used without further purification. Gaseous CO used in the diglyme synthesis of the $\left(\mathrm{Et}_{4} \mathrm{~N}\right)_{2}\left[\mathrm{Tc}(\mathrm{CO})_{3} \mathrm{Cl}_{3}\right]$ was obtained from Matheson Tri-Gas. Inorganic sodium salts were 
obtained from Sigma-Aldrich and were of reagent grade. All aqueous solutions were prepared from distilled deionized water (DIW) deionized to $\geq 15 \mathrm{M} \Omega \mathrm{cm}$ with a Barnstead Nanopure water purification system.

\subsection{Synthesis of $\left[\mathrm{Tc}(\mathrm{CO})_{3}\right]^{+}$}

$\left(\mathrm{Et}_{4} \mathrm{~N}\right)_{2}\left[\mathrm{Tc}(\mathrm{CO})_{3} \mathrm{Cl}_{3}\right]$ was prepared by the two-step reduction of ammonium pertechnetate as described elsewhere (Levitskaia et al. 2014). It was used to generate analytically pure tetrameric $\left[\mathrm{Tc}(\mathrm{CO})_{3}(\mathrm{OH})\right]_{4}$ species according to modified literature procedure (Alberto et al. 1998) by dissolution in $\mathrm{NaOH}$ solution and extraction of the product into diethyl ether.

\subsection{Synthesis of $\left[\mathrm{Tc}(\mathrm{CO})_{2}(\mathrm{NO})\right]^{2+}$ Derivatives}

The $\left[\mathrm{Tc}(\mathrm{CO})_{2}(\mathrm{NO})\right]^{2+}$ complex species were generated by substitution of one $\mathrm{CO}$ with one $\mathrm{NO}^{+}$ ligand in the $\left[\mathrm{Tc}(\mathrm{CO})_{3}\right]^{+}$core using either $\left(\mathrm{Et}_{4} \mathrm{~N}\right)_{2}\left[\mathrm{Tc}(\mathrm{CO})_{3} \mathrm{Cl}_{3}\right]$ or $\left[\mathrm{Tc}(\mathrm{CO})_{3}(\mathrm{OH})\right]_{4}$ as precursor. The $\left[\mathrm{Tc}(\mathrm{CO})_{3}\right]^{+}$compound was treated with the nitrosyl donor $\mathrm{NOBF}_{4}$ in chlorinated organic solvent $\mathrm{CH}_{2} \mathrm{Cl}_{2}$ following a modified literature procedure (Rattat et al. 2001, 2004). The general procedure is as follows.

- $0.02 \mathrm{~g}$ of $\left(\mathrm{Et}_{4} \mathrm{~N}\right)_{2}\left[\mathrm{Tc}(\mathrm{CO})_{3} \mathrm{Cl}_{3}\right]$ or $\left[\mathrm{Tc}(\mathrm{CO})_{3}(\mathrm{OH})\right]_{4}$ was dissolved in $5 \mathrm{~mL} \mathrm{CH}_{2} \mathrm{Cl}_{2}$.

- $0.02-0.05$ g solid $\mathrm{NOBF}_{4}$ was added to the $\mathrm{CH}_{2} \mathrm{Cl}_{2}$ solution.

- The inhomogeneous mixture was stirred for 2-7 days. Over time the solution changed color from off-white to yellow.

- Yellow precipitate was formed, separated from the solution by decantation, and washed with $\mathrm{CH}_{2} \mathrm{Cl}_{2}$.

\subsection{Characterization Methods}

Technetium-99 nuclear magnetic resonance (NMR) spectroscopy. The NMR sample solutions were placed in capped polytetrafluoroethylene (PTFE)/fluorinated ethylene propylene (FEP) copolymer sleeves (Wilmad Lab Glass, Vineland, NJ), which were then inserted into 5- or 10-mm glass NMR tubes to provide secondary containment for the radioactive liquid. Technetium-99 NMR data were routinely collected at $67.565 \mathrm{MHz}$ on a Tecmag Discovery spectrometer equipped with a 10-mm broadband Nalorac probe as described in Cho et al. (2004) at the RPL at PNNL. A solution containing $10 \mathrm{mM} \mathrm{TcO}_{4}{ }^{-}$ was used as a Tc-99 chemical shift reference, and all chemical shift data are quoted relative to $\mathrm{TcO}_{4}{ }^{-}$ (Franklin et al. 1982).

Technetium-99 electron paramagnetic resonance (EPR) spectroscopy. EPR spectra were acquired on a Bruker EMX Spectrometer equipped with an ER4102ST resonator (spectra at room temperature and $120 \mathrm{~K}$ ) or an ER4116DM Dual Mode resonator (spectra at $5 \mathrm{~K}$ ) and an Oxford ESR910 cryostat. Samples were doubly contained by employing unbreakable FEP tube liners (Wilmad Lab Glass, Vineland, NJ) inside traditional quartz EPR tubes. Liquid samples employed $1.5 \mathrm{~mm}$ inner diameter (ID) liners and $4 \mathrm{~mm}$ outer diameter (OD) quartz tubes while frozen solution and powder samples used $3.15 \mathrm{~mm}$ ID liners and $5 \mathrm{~mm}$ OD tubes. 
Fourier Transform Infrared (FTIR) spectroscopy. FTIR measurements were conducted using a spectrometer (ALPHA model, Bruker Optics) operated with OPUS software (Version 6.5 Build 6.5.92). Samples were run directly on a diamond attenuated total reflectance (ATR) cell. For each sample, 24 scans with a resolution of 4 wavenumbers $\left(\mathrm{cm}^{-1}\right)$ were averaged to give the final spectrum. A background of ambient air was used for all samples. A sample volume of approximately $10 \mu \mathrm{L}$ was used for each analysis; this was adequate to cover the collection region of the ATR cell.

\subsection{Theoretical Calculations}

Density Functional Theory (DFT) computations were carried out using the ORCA software program (Neese 2012) utilizing the B3LYP functional, def2-TZVPP basis set (Schäfer et al. 1992; Weigend and Ahlrichs 2005). Solvation effects where accounted for using COSMO with appropriate dielectric constant and polarizability for each solvent examined. Relativistic effects were handled using the zeroth order regular approximation (ZORA) to the Dirac equation. Computations were performed on clusters available through PNNL Institutional Computing (PIC). The computations were validated by comparison to chemical shifts from known literature values, namely in this instance against $\left[\mathrm{Tc}(\mathrm{CO})_{2}(\mathrm{NO})(\mu-\mathrm{Cl}) \mathrm{Cl}\right]_{2}$ (experimental: $-389 \mathrm{ppm}$ [Schibli et al. 2005], DFT: $-263 \mathrm{ppm}$ ) and $\left[\mathrm{Tc}(\mathrm{CO})_{2}(\mathrm{NO}) \mathrm{Cl}_{3}\right]^{-}$ (experimental: $-460 \mathrm{ppm}$ [Schibli et al. 2005], DFT: $-559 \mathrm{ppm}$ ).

\subsection{Results and Discussion}

\subsection{Characterization of the $\left[\mathrm{Tc}(\mathrm{CO})_{2}(\mathrm{NO})\right]^{2+}$ Products Obtained Using $\left(\mathrm{Et}_{4} \mathrm{~N}\right)_{2}\left[\mathrm{Tc}(\mathrm{CO})_{3} \mathrm{Cl}_{3}\right]$ Precursor}

The synthetic protocol using $\left(\mathrm{Et}_{4} \mathrm{~N}\right)_{2}\left[\mathrm{Tc}(\mathrm{CO})_{3} \mathrm{Cl}_{3}\right]$ precursor generated the heterogeneous reaction mixture containing yellow solution and precipitate. Liquid scintillation counting (LSC) indicated that precipitate and supernatant contain 35 and 65\%, respectively, of the known starting Tc amount used in the reaction. The Tc-based reaction yield was estimated to be about $70 \%$ with $30 \%$ of starting Tc oxidized to Tc(VII) (Tables 1 and 2 below).

\subsubsection{Characterization of the $\left[\mathrm{Tc}(\mathrm{CO})_{2}(\mathrm{NO})\right]^{2+}$ Products in the Reaction Supernatant}

Technetium-99 NMR analysis of the supernatant solution in the methylene chloride $\left(\mathrm{CH}_{2} \mathrm{Cl}_{2}\right)$ solvent showed three Tc resonances at $-332,-367$, and $-477 \mathrm{ppm}$ in addition to three resonances near $0 \mathrm{ppm}$ (Figure 1). The chemical shifts, line widths, and percentage composition of the species associated with each resonance are listed in Table 1. 


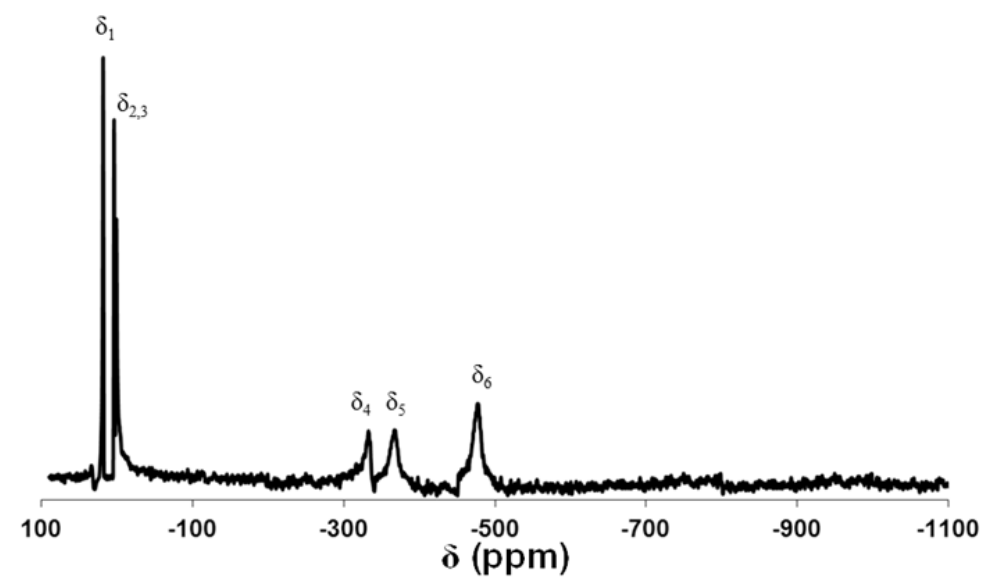

Figure 1. Technetium-99 NMR Spectrum of the $\mathrm{CH}_{2} \mathrm{Cl}_{2}$ Supernatant Obtained by the Reaction of $\left[\mathrm{Tc}(\mathrm{CO})_{3} \mathrm{Cl}_{3}\right]^{2-}$ with $\mathrm{NOBF}_{4} . \delta_{1}=17 \mathrm{ppm}, \delta_{2}=3 \mathrm{ppm}, \delta_{3}=0 \mathrm{ppm}, \delta_{4}=-332 \mathrm{ppm}$, $\delta_{5}=-367 \mathrm{ppm}, \delta_{6}=-477 \mathrm{ppm}$.

Table 1. Techetium-99 NMR Characterization of the $\mathrm{CH}_{2} \mathrm{Cl}_{2}$ Supernatant Solution Obtained by the Reaction of $\left[\mathrm{Tc}(\mathrm{CO})_{3} \mathrm{Cl}_{3}\right]^{2-}$ with $\mathrm{NOBF}_{4}$

\begin{tabular}{|c|c|c|c|c|c|}
\hline $\begin{array}{l}\text { Experimental } \\
{ }^{99} \text { Tc Chemical } \\
\text { Shift, ppm }\end{array}$ & $\begin{array}{c}\text { DFT } \\
\text { Calculated } \\
{ }^{99} \text { Tc } \\
\text { Chemical } \\
\text { Shift, ppm }\end{array}$ & $\begin{array}{c}\text { Half Width } \\
\text { of }{ }^{99} \text { Tc } \\
\text { Resonance, } \\
\text { Hz }\end{array}$ & 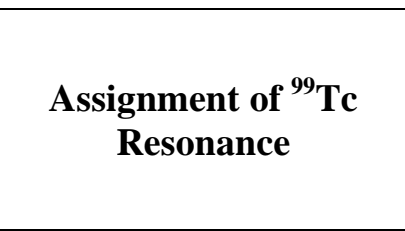 & $\begin{array}{c}\text { \% of }{ }^{99} \mathrm{Tc} \text { in } \\
\text { Supernatant }{ }^{\mathrm{a})}\end{array}$ & $\begin{array}{l}\% \text { of Total } \\
\text { Reaction } \\
\text { Product }\end{array}$ \\
\hline 17 & 28 & 40 & $\mathrm{HTcO}_{4}$ & 17 & 11 \\
\hline 3 & - & 50 & $\mathrm{Et}_{4} \mathrm{NTcO}_{4}$ & 15 & 10 \\
\hline 0 & - & 40 & $\mathrm{TcO}_{4}^{-}$ & 11 & 7.5 \\
\hline-332 & -261 & 410 & {$\left[\mathrm{Tc}(\mathrm{CO})_{2}(\mathrm{NO})(\mu-\mathrm{Cl}) \mathrm{Cl}\right]_{2}$} & 11 & 7.0 \\
\hline-367 & -332 & 550 & {$\left[\mathrm{Tc}(\mathrm{CO})_{2}(\mathrm{NO})(\mu-\mathrm{Cl}) \mathrm{Cl}\right]_{2}$} & 15 & 9.5 \\
\hline-477 & -559 & 700 & {$\left[\mathrm{Tc}(\mathrm{CO})_{2}(\mathrm{NO}) \mathrm{Cl}_{3}\right]^{-}$} & 31 & 20 \\
\hline
\end{tabular}

The NMR measured resonance peaks at 0,3 , and $17 \mathrm{ppm}$ are attributed to the dissociated $\mathrm{TcO}_{4}{ }^{-}$and associated $\mathrm{Et}_{4} \mathrm{NTcO}_{4}$ and $\mathrm{HTcO}_{4}$ species, respectively. This assignment is supported by the established NMR properties of the pertechnetate salts including chemical shifts and narrow line widths (Cho et al. 2004) and DFT computations conducted in this work suggesting that the Tc-99 resonance position corresponding to the $\mathrm{HTcO}_{4}$ acid is positively shifted from dissociated $\mathrm{TcO}_{4}{ }^{-}$(Table 1).

Three observed resonances at $-332,-367$, and -477 ppm are distinctly different from the Tc-99 resonance of the $\left[\mathrm{Tc}(\mathrm{CO})_{3} \mathrm{Cl}_{3}\right]^{2-}$ starting material, which appears at $-1135 \mathrm{ppm}$ and has narror line width of $120 \mathrm{~Hz}$ based on the our measurements. Such a downfield shift is consistent with substitution of CO 
with the less $\sigma$-donating and more $\pi$-accepting $\mathrm{NO}^{+}$group and the resonances are attributed to $\left[\mathrm{Tc}(\mathrm{CO})_{2}(\mathrm{NO})\right]^{2+}$ species, which are consistent with the infrared spectroscopy (IR) analyses described below. The presence of three Tc-99 resonances is suggestive of three distinct $\left[\mathrm{Tc}(\mathrm{CO})_{2}(\mathrm{NO})\right]^{2+}$ environments. Schibli and coworkers reported formation of both monomeric $\left[\mathrm{Tc}(\mathrm{CO})_{2}(\mathrm{NO}) \mathrm{Cl}_{3}\right]^{-}$and Cl-bridged dimeric $\left[\mathrm{Tc}(\mathrm{CO})_{2}(\mathrm{NO})(\mu-\mathrm{Cl}) \mathrm{Cl}\right]_{2}$ products upon nitrosylation of $\left[\mathrm{Tc}(\mathrm{CO})_{3} \mathrm{Cl}_{3}\right]^{2-}$ in chlorinated organic medium (Schibli et al. 2005). Based on similarity with these observations, the resonance at $-477 \mathrm{ppm}$ is attributed to the monomeric $\left[\mathrm{Tc}(\mathrm{CO})_{2}(\mathrm{NO}) \mathrm{Cl}_{3}\right]^{-}$species, while the resonance at $-367 \mathrm{ppm}$ is attributed to a trans- $\left[\mathrm{Tc}(\mathrm{CO})_{2}(\mathrm{NO})(\mu-\mathrm{Cl}) \mathrm{Cl}\right]_{2}$ species as shown in Figure 2, A. A similar dimerization was also observed by Kurz and coworkers (Kurz et al. 2005) during the nitrosylation of an analogous Re complex.

Appearance of the third $\left[\mathrm{Tc}(\mathrm{CO})_{2}(\mathrm{NO})\right]^{2+}$ species in the nitrolysation reaction has not been previously reported. However, it should be noted that while only one isomer is possible for the mono-nitrosylated monomeric species as shown in Figure 3, five different isomers of Cl-bridged dimeric species are possible during the mononitrosylation of Tc centers as shown in Figure 2. However, based on the trans-influence of the $\mathrm{NO}^{+}$group, we hypothesize that the preponderance of the trans isomers (Figure 2, $\mathbf{A}$ and $\mathbf{B}$ ) are more likely present compared to the cis isomers (Figure 2, C, D, and E). While the error in the DFT calculated chemical shift of the dimers is likely larger than the $35 \mathrm{ppm}$ shift experimentally observed between the two dimer isomers, all calculated dimer shifts are within the range experimentally seen, suggesting a dimer is in fact responsible for these two resonances. The computed energies are also in line with the aforementioned trans influence, suggesting that the trans isomers are more stable than their cis counterparts. Therefore, we attribute the resonances at $-332 \mathrm{ppm}$ and $-367 \mathrm{ppm}$ to the dimeric trans isomers shown in Figure 2, $\mathbf{A}$ and $\mathbf{B}$, respectively. Therefore, the proposed nitrolysation reaction can be written as shown in Scheme 2, resulting in the formation of one monomeric and two dimeric products.

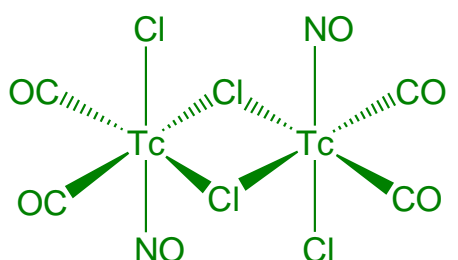

A

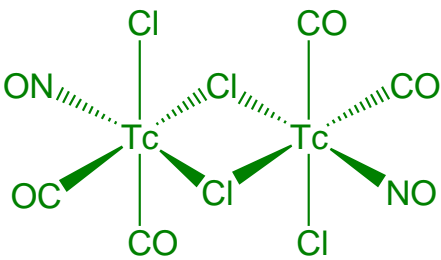

B
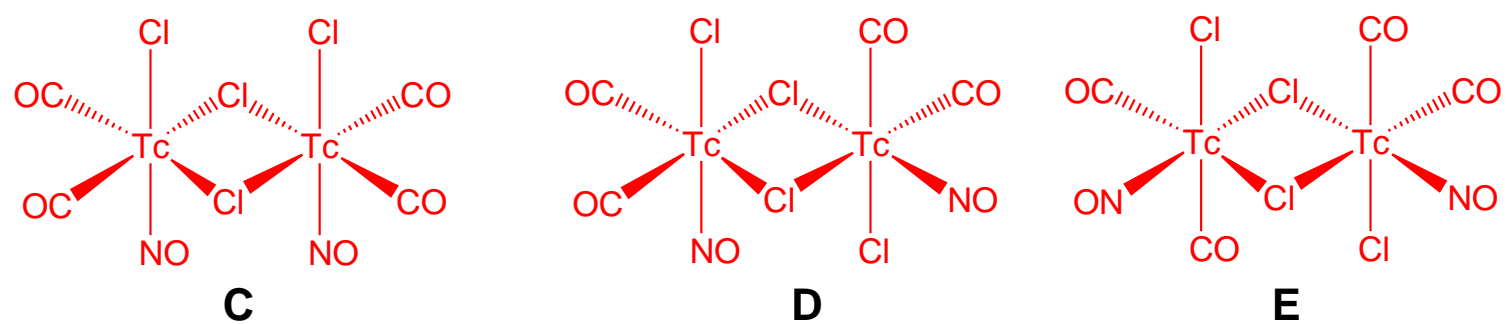

Figure 2. Molecular Structures of the Proposed Cl-bridged Dimeric $\left[\mathrm{Tc}(\mathrm{CO})_{2}(\mathrm{NO})\right]^{2+}$-based Species Formed by the Mononitrosylation of the Tc Carbonyl Centers 


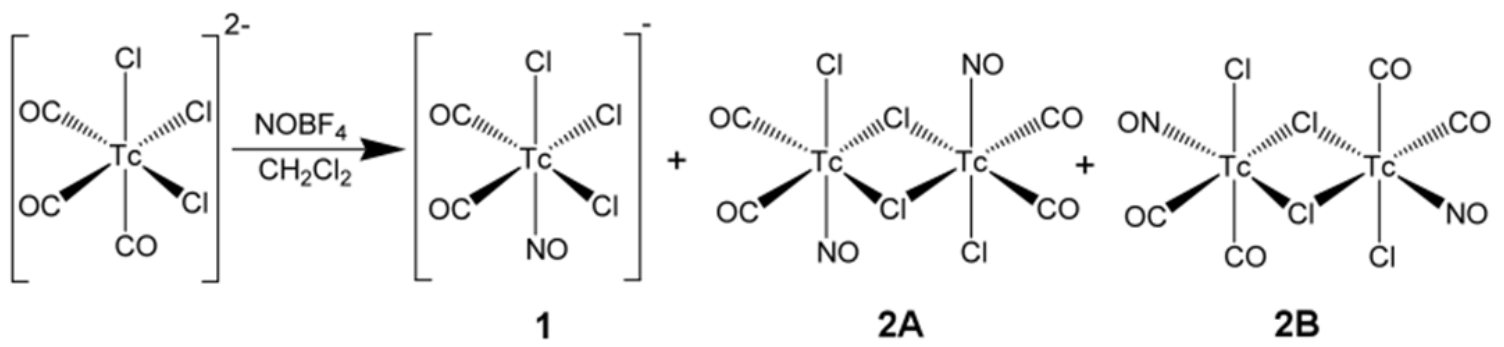

Scheme 2. Proposed Mechanism of Nitrolysation Reaction of $\left[\mathrm{Tc}(\mathrm{CO})_{3} \mathrm{Cl}_{3}\right]^{2-}$ with $\mathrm{NOBF}_{4}$

The IR spectrum of the reaction supernatant (Figure 3) shows features that are distinctly different compared to the starting $\left[\mathrm{Tc}(\mathrm{CO})_{3} \mathrm{Cl}_{3}\right]^{2-}$ complex. Compared to characteristic $\mathrm{C}-\mathrm{O}_{\text {str }}$ vibration bands of $\left[\mathrm{Tc}(\mathrm{CO})_{3} \mathrm{Cl}_{3}\right]^{2-}$ at $2018 \mathrm{~cm}^{-1}$ with $1914 \mathrm{~cm}^{-1}$ shoulder and $1892 \mathrm{~cm}^{-1}$ attributed to the compound's symmetric in-plane, symmetric out-of-plane, and asymmetric stretches (Alberto et al. 1995; Dattelbaum et al. 2002), the corresponding vibrational bands of the $\left[\mathrm{Tc}(\mathrm{CO})_{2}(\mathrm{NO})\right]^{2+}$ product are shifted to higher energy and centered at 2131 (overlap of two bands) and $2077 \mathrm{~cm}^{-1}$. Additionally, a strong new band is observed at $1817 \mathrm{~cm}^{-1}$ assigned to the nitrosyl group in addition to weaker bands at 1933 and $1734 \mathrm{~cm}^{-1}$. Computationally predicted IR bands for $\left[\mathrm{Tc}(\mathrm{CO})_{2}(\mathrm{NO}) \mathrm{Cl}_{3}\right]^{-}$at 2149,2071 , and $1822 \mathrm{~cm}^{-1}$ are in excellent agreement with the experimentally observed bands at 2131,2077, and $1817 \mathrm{~cm}^{-1}$. This assignment is also consistent with what was observed by Schibli and coworkers including 2116 (CO), 2062 (CO), and $1775 \mathrm{~cm}^{-1}$ (NO) (Schibli et al. 2005). While Schibli and coworkers assign the bands at $2116 \mathrm{~cm}^{-1}$ and $2062 \mathrm{~cm}^{-1}$ primarily to $\mathrm{CO}$ vibrations, and $1775 \mathrm{~cm}^{-1}$ to NO vibrations, our computational modelling shows all the three bands to have contributions from both the $\mathrm{CO}$ and NO vibrations.

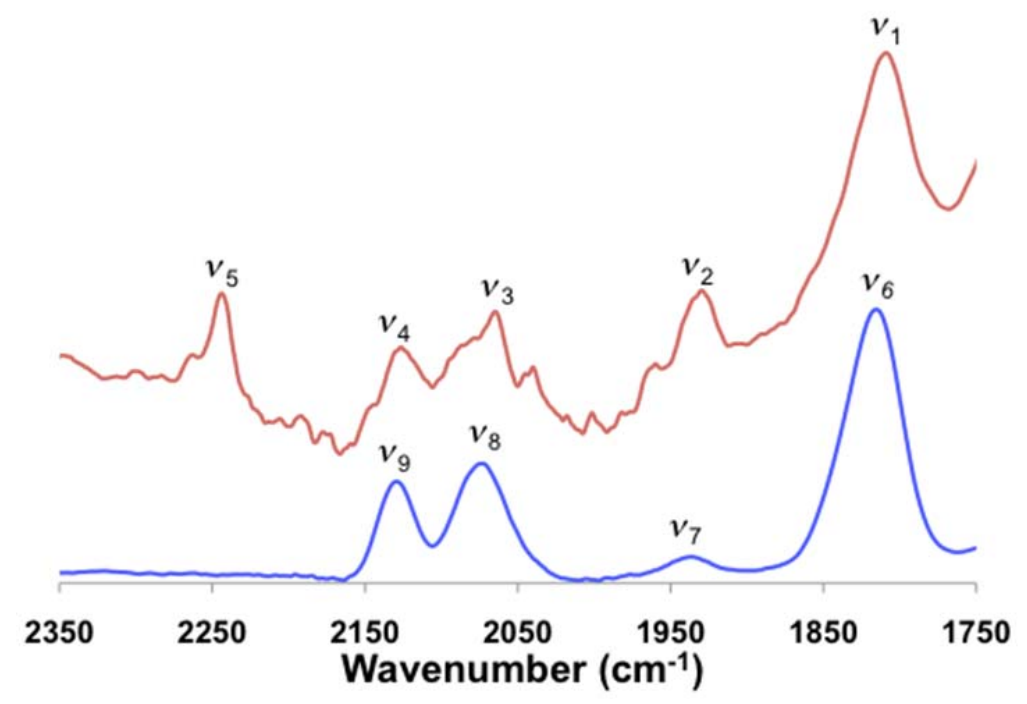

Figure 3. Infrared Spectra of the Supernatant $\mathrm{CH}_{2} \mathrm{Cl}_{2}$ Solution (lower, blue trace) and the Solid Precipitate (upper, red trace) Obtained by the Reaction of $\left[\mathrm{Tc}(\mathrm{CO})_{3} \mathrm{Cl}_{3}\right]^{2-}$ with $\mathrm{NOBF}_{4}$. Frequencies, $\mathrm{cm}^{-1}: v_{1}=1811, v_{2}=1927, v_{3}=2067, v_{4}=2129, v_{5}=2246, v_{6}=1817$, $v_{7}=1933, v_{8}=2073, v_{9}=2131$. 


\subsubsection{Characterization of the $\left[\mathrm{Tc}(\mathrm{CO})_{2}(\mathrm{NO})\right]^{2+}$ Products in the Reaction Solid Fraction}

To characterize the solid reaction product, it was dissolved in ethanol (EtOH). Technetium-99 NMR analysis of the resulting solution showed three Tc resonances at $-242,-293$, and $-388 \mathrm{ppm}$ in addition to one resonance at $0 \mathrm{ppm}$ (Figure 4). The chemical shifts, line widths, and percentage composition of the species associated with each resonance are listed in Table 2.

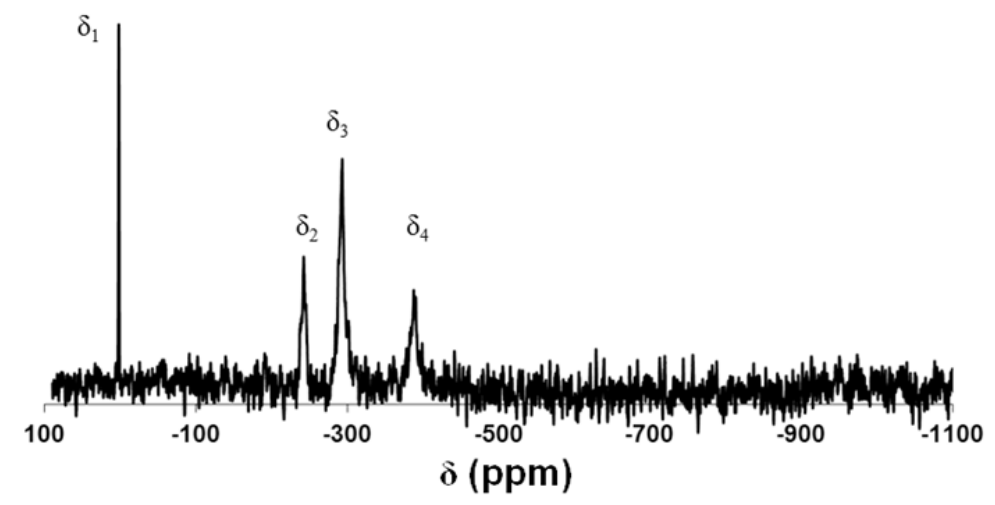

Figure 4. Technetium-99 NMR Spectrum of the Precipitate Obtained from the Reaction of $\left[\mathrm{Tc}(\mathrm{CO})_{3} \mathrm{Cl}_{3}\right]^{2-}$ with $\mathrm{NOBF}_{4}$ and Dissolved in EtOH. $\delta_{1}=0$ ppm, $\delta_{2}=-242 \mathrm{ppm}$, $\delta_{3}=-293 \mathrm{ppm}, \delta_{4}=-388 \mathrm{ppm}$.

Table 2. Techetium-99 NMR Characterization of the Precipitate Obtained by the Reaction of $\left[\mathrm{Tc}(\mathrm{CO})_{3} \mathrm{Cl}_{3}\right]^{2-}$ with $\mathrm{NOBF}_{4}$ Dissolved in $\mathrm{EtOH}$

\begin{tabular}{|c|c|c|c|c|c|}
\hline $\begin{array}{c}\underset{99}{\text { Experimental }} \\
{ }_{\text {Tc }} \\
\text { Chemical } \\
\text { Shift, ppm }\end{array}$ & $\begin{array}{c}\text { DFT } \\
\text { Calculated } \\
{ }_{99} \text { Tc } \\
\text { Chemical } \\
\text { Shift, ppm } \\
\end{array}$ & $\begin{array}{c}\text { Half Width of } \\
{ }_{\text {99 }} \text { Tc } \\
\text { Resonance, } \\
\text { Hz }\end{array}$ & $\begin{array}{l}\text { Assignment of } \\
\text { Resonance }\end{array}$ & $\begin{array}{l}\text { \% of }{ }^{99} \mathrm{Tc} \\
\text { in NMR } \\
\text { Sample }^{\mathrm{a})}\end{array}$ & $\begin{array}{c}\text { \% of } \\
\text { Total } \\
\text { Reaction } \\
\text { Product }^{\text {b) }}\end{array}$ \\
\hline 0 & & 40 & $\mathrm{TcO}_{4}^{-}$ & 7 & 2.6 \\
\hline-242 & -260 & 400 & {$\left[\mathrm{Tc}\left(\mathrm{H}_{2} \mathrm{O}\right)_{3}(\mathrm{CO})_{2}(\mathrm{NO})\right]^{2+}$} & 18 & 6.2 \\
\hline-293 & -322 & 500 & {$\left[\mathrm{TcCl}\left(\mathrm{H}_{2} \mathrm{O}\right)_{2}(\mathrm{CO})_{2}(\mathrm{NO})\right]^{+}$} & 57 & 20 \\
\hline-388 & -560 & 450 & {$\left[\mathrm{TcCl}_{2}\left(\mathrm{H}_{2} \mathrm{O}\right)(\mathrm{CO})_{2}(\mathrm{NO})\right]$} & 18 & 6.2 \\
\hline
\end{tabular}

The Tc-99 resonance at $0 \mathrm{ppm}$ is the characteristic for $\mathrm{TcO}_{4}{ }^{-}$(Cho et al. 2004). The resonances between -200 and $-400 \mathrm{ppm}$ are distinctly different from the resonance of the starting $\left[\mathrm{TcCl}_{3}(\mathrm{CO})_{3}\right]^{2-}$ material observed in EtOH at $-872 \mathrm{ppm}$ due to the formation of the tri-aqua $\left[\mathrm{Tc}\left(\mathrm{H}_{2} \mathrm{O}\right)_{3}(\mathrm{CO})_{3}\right]^{+}$species as a result of $\mathrm{Cl}^{-}$ligands being exchanged with $\mathrm{H}_{2} \mathrm{O}$ present in EtOH. The pattern of the resonances is similar to that observed in $\mathrm{CH}_{2} \mathrm{Cl}_{2}$ supernatant, and the signals are attributed to the monomer $\left[\mathrm{Tc}(\mathrm{CO})_{2}(\mathrm{NO}) \mathrm{Cl}_{3}\right]^{-}$and the two trans Cl-bridged dimers $\left[\mathrm{Tc}(\mathrm{CO})_{2}(\mathrm{NO})(\mu-\mathrm{Cl}) \mathrm{Cl}\right]_{2}$ represented by 
molecules $\mathbf{A}$ and $\mathbf{B}$ in Figure 2. The different positions of the resonances observed in $\mathrm{CH}_{2} \mathrm{Cl}_{2}$ and EtOH solvents are explained by the different mode of solvation; however, the exchange of the chloride ligand by either water present in the ethanol or EtOH molecules is also possible.

It is interesting to note that the yellow solution obtained by the dissolution of the reaction precipitate dissolved in DIW exhibited drastic color change to an intense red within 30-60 minutes. Technetium-99 NMR of the red aqueous solution initially showed no presence of the Tc-99 resonances (Figure 5), which was explained by the potential oxidation of the $\mathrm{Tc}(\mathrm{I})\left[\mathrm{Tc}(\mathrm{CO})_{2}(\mathrm{NO})\right]^{2+}$ or $\left[\mathrm{Tc}(\mathrm{CO})_{3}\right]^{+}$species to the NMRinactive Tc(II) analogs. It is significant that only about $5-10 \%$ of total Tc present in the sample got oxidized to $\mathrm{TcO}_{4}{ }^{-}$in 30 days (Figure 5; green trace [second from bottom]) as determined based on the integration of signal intensity from a $\mathrm{TcO}_{4}{ }^{-}$standard of known concentration. This is in contrast to the $\mathrm{Tc}(\mathrm{I})\left[\mathrm{Tc}(\mathrm{CO})_{3}\right]^{+}$species, which undergo fast oxidative hydrolysis to form $\mathrm{TcO}_{4}{ }^{-}$in aqueous solutions with low ionic strength (Rapko et al. 2013; Levitskaia et al. 2014). When the yellow reaction precipitate was dissolved in $5 \mathrm{M} \mathrm{NaNO}_{3}$, it demonstrated similar but significantly less intense color change from yellow to red. The NMR analysis of this solution showed no presence of the Tc-99 resonances within 3 days. Monitoring of DIW and $5 \mathrm{M} \mathrm{NaNO}_{3}$ samples is currently in progress.

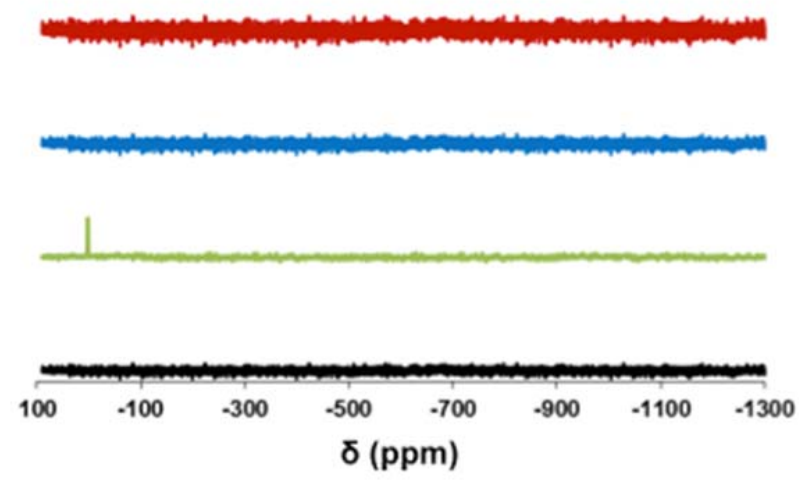

Figure 5. Technetium-99 NMR Spectra of the Precipitate Obtained by the Reaction of $\left[\mathrm{Tc}(\mathrm{CO})_{3} \mathrm{Cl}_{3}\right]^{2-}$ with $\mathrm{NOBF}_{4}$ Dissolved in Water and Recorded at $\mathrm{t}=30$ Minutes (black trace $[$ bottom]) and at $t=30$ Days (green trace [second from bottom]) or Dissolved in Aqueous $5 \mathrm{M} \mathrm{NaNO}_{3}$ Solution and Recorded at $\mathrm{t}=30$ Minutes (blue trace [second from top]) and at $\mathrm{t}=3$ Days (red trace [top]) After Sample Preparation. Monitoring of DIW and $5 \mathrm{M} \mathrm{NaNO}_{3}$ samples is currently continuing.

To confirm conversion of $\mathrm{Tc}(\mathrm{I})$ to $\mathrm{Tc}(\mathrm{II})$ in the solid $\left[\mathrm{Tc}(\mathrm{CO})_{2}(\mathrm{NO})\right]^{2+}$ product upon dissolution in water, it was characterized by Tc-99 EPR spectroscopy. An EPR analysis of the red water solution showed a series of 10 resonances, a system characteristic of Tc(II) with spin=1/2 (Figure 6). This is indicative of oxidation of the $\operatorname{Tc}(\mathrm{I})$ center in water, resulting in the generation of an evenly charged paramagnetic species. 


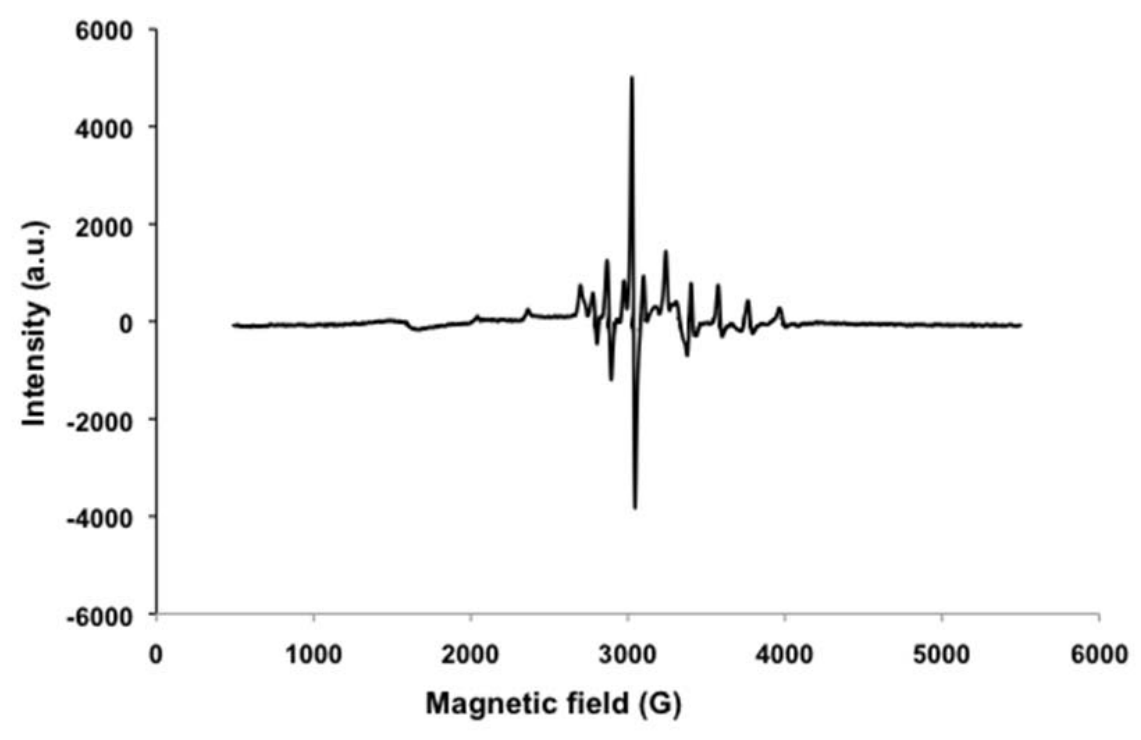

Figure 6. Technetium-99 EPR Spectrum of the Aqueous Solution of the Precipitate (dissolved) Obtained from the Reaction of $\left[\mathrm{Tc}(\mathrm{CO})_{3} \mathrm{Cl}_{3}\right]^{2-}$ with $\mathrm{NOBF}_{4}$

The solid reaction fraction was characterized by IR spectroscopy, and the obtained spectrum exhibited a similar profile to that of the corresponding liquid reaction fraction (Figure 3). This result confirms the presence of $\left[\mathrm{Tc}(\mathrm{CO})_{2}(\mathrm{NO})\right]^{2+}$ in the reaction precipitate.

\subsection{Characterization of the $\left[\mathrm{Tc}(\mathrm{CO})_{2}(\mathrm{NO})\right]^{2+}$ Products Obtained Using $\left[\mathrm{Tc}(\mathrm{CO})_{3} \mathrm{OH}\right]_{4}$ Precursor}

The synthetic protocol using $\left[\mathrm{Tc}(\mathrm{CO})_{3} \mathrm{OH}\right]_{4}$ precursor generated a heterogeneous reaction mixture containing solution and an orange-brown precipitate. Liquid scintillation counting indicated that the precipitate contained $>98 \%$ of the starting Tc, suggesting complete precipitation of the product and nearly quntitative reaction yield. To characterize the reaction precipitate, it was dissolved in various solvents and analyzed by Tc-99 NMR.

The Tc-99 NMR spectrum corresponding to dissolution of the precipitate in diethyl ether, $\mathrm{Et}_{2} \mathrm{O}$, contains a single resonance at $-184 \mathrm{ppm}$, suggesting a single $\left[\mathrm{Tc}(\mathrm{CO})_{2}(\mathrm{NO})\right]^{2+}$ environment. It is interesting to note that this Tc complex exhibits a high stability in $\mathrm{Et}_{2} \mathrm{O}$, revealing an identical spectrum even after a month, with no oxidative decomposition of $\left[\mathrm{Tc}(\mathrm{CO})_{2}(\mathrm{NO})\right]^{2+}$ within 30 days (Figure 7). 


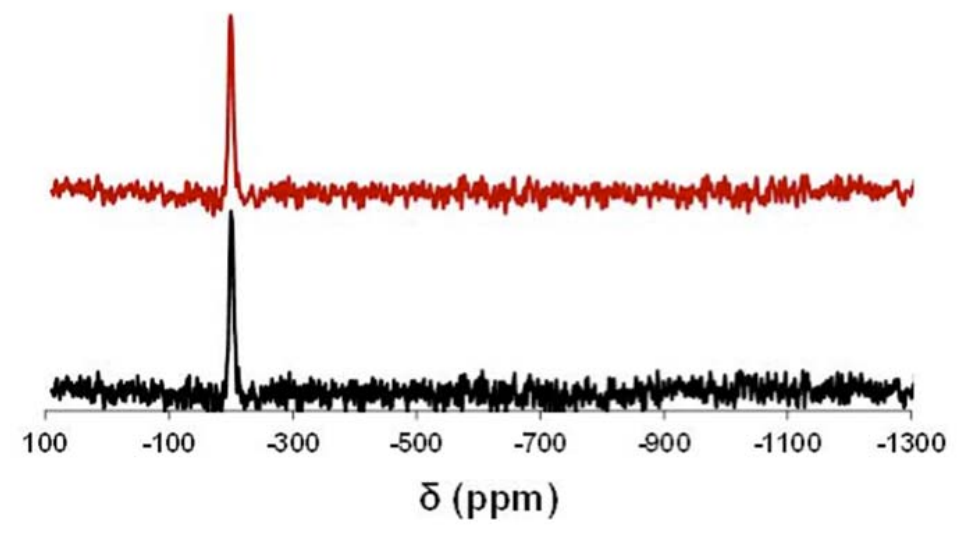

Figure 7. Technetium-99 NMR Spectra in Diethyl Ether of the Precipitate Obtained by the Reaction of $\left[\mathrm{Tc}(\mathrm{CO})_{3}(\mathrm{OH})\right]_{4}$ with $\mathrm{NOBF}_{4}$ Recorded at 30 min (black trace [lower]) and 30 Days (red trace [upper]) After Sample Preparation. Monitoring of this sample is currently continuing.

The Tc-99 NMR spectrum of the precipitate dissolved in acetonitrile $(\mathrm{MeCN})$ and recorded within 30 minutes after sample preparation exhibited three resonances at $-373,-428$, and -1091 ppm (Figure 8). The resonances at -373 and $-428 \mathrm{ppm}$ are observed to gradually decrease in intensity while the resonance at $-1091 \mathrm{ppm}$ is observed to grow in the 3-day-old sample. Based on the similarity in chemical shifts with the products obtained using $\left[\mathrm{Tc}(\mathrm{CO})_{3} \mathrm{Cl}_{3}\right]^{2-}$ starting material, the resonances at -373 and $-428 \mathrm{ppm}$ are tentatively assigned to the two trans dimers (axial and equatorial) $\left[\mathrm{Tc}(\mathrm{CO})_{2}(\mathrm{NO})(\mu-\mathrm{Cl}) \mathrm{Cl}\right]_{2}($ molecules $\mathbf{A}$ and $\mathbf{B}$ in Figure 2). It is hypothesized that the dimers dissociate over time due to exchange of $\mathrm{Cl}$ ligand with coordinating $\mathrm{MeCN}$ solvent to form $\left[\mathrm{Tc}(\mathrm{CO})_{2}(\mathrm{NO}) \mathrm{Cl}_{2}(\mathrm{MeCN})\right]$ monomer, which has a chemical shift of $-1091 \mathrm{ppm}$. Interestingly, no $\mathrm{TcO}_{4}{ }^{-}$formation is observed in either the liquid or solid reaction fraction.

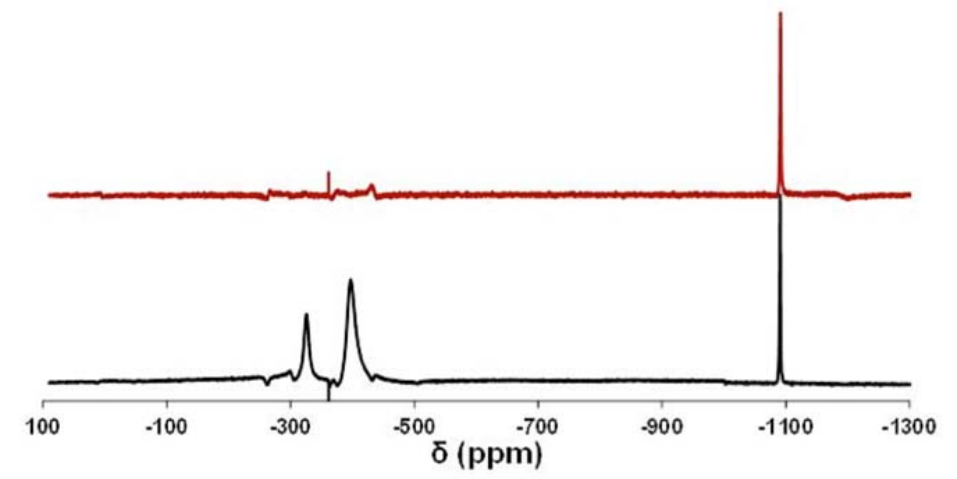

Figure 8. Technetium-99 NMR Spectra in Acetonitrile Solution of the Precipitate Obtained by the Reaction of $\left[\mathrm{Tc}(\mathrm{CO})_{3}(\mathrm{OH})\right]_{4}$ with $\mathrm{NOBF}_{4}$ Recorded at 30 min (black trace [lower]) and 3 days (red trace [upper]) After Sample Preparation

The Tc-99 NMR spectrum of the precipitate dissolved in tetrahydrofuran (THF) showed two resonances at -176 and -201 ppm (spectrum not shown) tentatively assigned to the two trans dimers (axial 
and equatorial) $\left[\mathrm{Tc}(\mathrm{CO})_{2}(\mathrm{NO})(\mu-\mathrm{Cl}) \mathrm{Cl}\right]_{2}$ (molecules $\mathbf{A}$ and $\mathbf{B}$ in Figure 2). The downfield shift of these resonances in comparison with the $\mathrm{MeCN}$ solution of the reaction product is consistent with the less coordinating nature of the THF solvent.

Dissolution of the orange-brown precipitate in water resulted in its complete dissolution. The color of the solution changed to an intense red within 30-60 minutes of the solution preparation. This observation is similar to that for the precipitate obtained during the reaction of $\left[\mathrm{Tc}(\mathrm{CO})_{3} \mathrm{Cl}_{3}\right]^{2-}$ with $\mathrm{NOBF}_{4}$. Likewise, NMR of the red aqueous solution did not show the presence of any Tc resonances (Figure 9), which was attributed to the conversion of Tc(I) to NMR-inactive Tc(II) species. The monitoring of this solution for 30 days did not show appearance of any Tc-99 NMR-active species, including $\mathrm{TcO}_{4}^{-}$, suggesting high oxidative stability of this low-valent Tc(II) product. Also, dissolution of the precipitate in $5 \mathrm{M} \mathrm{NaNO}_{3}$ solution resulted in a similar but less intense color change to red. No formation of pertechnetate was observed within a period of 7 days.

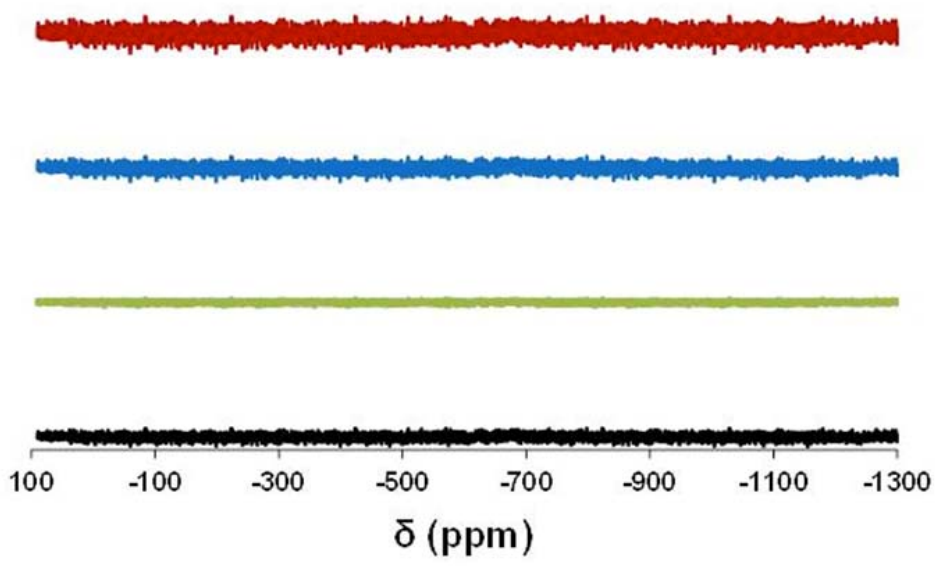

Figure 9. Technetium-99 NMR Spectra of the Precipitate Obtained by the Reaction of $\left[\mathrm{Tc}(\mathrm{CO})_{3}(\mathrm{OH})\right]_{4}$ with $\mathrm{NOBF}_{4}$ Dissolved in Water and Recorded at $\mathrm{t}=30$ Minutes (black trace $[$ bottom]) and at $t=30$ Days (green trace [second from bottom]) or Dissolved in Aqueous $5 \mathrm{M} \mathrm{NaNO}_{3}$ Solution and Recorded at $\mathrm{t}=30$ Minutes (blue trace [second from top]) and at $\mathrm{t}=7$ Days (red trace [top]) After Sample Preparation. Monitoring of DIW and $5 \mathrm{M} \mathrm{NaNO}_{3}$ samples is currently continuing.

\subsection{Conclusions}

Synthesis of low-valent Tc carbonyl nitrosyl complexes was performed using two Tc(I) tricarbonyl precursors, namely monomeric $\left[\mathrm{Tc}(\mathrm{CO})_{3} \mathrm{Cl}_{3}\right]^{2-}$ and tetrameric $\left[\mathrm{Tc}(\mathrm{CO})_{3}(\mathrm{OH})\right]_{4}$ species, in the methylene chloride solvent using $\mathrm{NOBF}_{4}$ as the nitrolysation reagent. Both pathways generated $\left[\mathrm{Tc}(\mathrm{CO})_{2}(\mathrm{NO})\right]^{2+}$ species as evident from the Tc-99 NMR and IR characterization of the reaction products. The reaction yield using $\left[\mathrm{Tc}(\mathrm{CO})_{3} \mathrm{Cl}_{3}\right]^{2-}$ starting material was about $70 \%$ with the Tc carbonyl nitrosyl species partitioned between a liquid and a solid reaction fraction that complicates isolation and purification of the product. In this procedure, about $30 \%$ of starting $\mathrm{Tc}(\mathrm{I})$ oxidized to $\mathrm{Tc}(\mathrm{VII})$. This oxidation can be potentially suppressed by shortening the reaction time and conducting it under an inert atmosphere. The 
reaction yield using $\left[\mathrm{Tc}(\mathrm{CO})_{3}(\mathrm{OH})\right]_{4}$ starting material was nearly quantitative with the Tc carbonyl nitrosyl product forming an insoluble precipitate, which can be easily separated from the reaction mixture.

It was observed that the Tc carbonyl nitrosyl product contained one monomeric $\left[\mathrm{Tc}(\mathrm{CO})_{2}(\mathrm{NO}) \mathrm{Cl}_{3}\right]^{-}$ and two trans Cl-bridged dimeric $\left[\mathrm{Tc}(\mathrm{CO})_{2}(\mathrm{NO})(\mu-\mathrm{Cl}) \mathrm{Cl}\right]_{2}$ species. However, this assignment should be confirmed by future studies. Structural characterization and assignment of the Tc carbonyl nitrosyl species is hindered by lack of model compounds and by the fact that few relevant studies have been conducted to date, so that the redox and chemical properties of these species have not been explored yet. To this end, the maturation of Tc computational modeling is of critical importance as it can assist and guide future experimentation and help in interpretation of the obtained results. In this work, DFT modeling was consistent with the NMR characterization of the Tc carbonyl nitrosyl product and helped in assignment of the observed signals.

The dissolution of the obtained Tc(I) carbonyl nitrosyl product in water and aqueous $5 \mathrm{M} \mathrm{NaNO}_{3}$ solution was accompanied by conversion of Tc(I) to Tc(II) species that were confirmed by Tc-99 EPR analysis and disappearance of the Tc(I) NMR resonances. The composition and structure of the resulting $\mathrm{Tc}(\mathrm{II})$ species should be elucidated in future studies. The preliminary results suggest that low-valent Tc carbonyl nitrosyl compounds showed no pertechnetate formation up to 30 days, and their monitoring is currently continuing. These preliminary results suggest that the low-valent Tc carbonyl nitrosyl compounds exhibit similar or greater oxidative stability than the $\mathrm{Tc}(\mathrm{I})\left[\mathrm{Tc}(\mathrm{CO})_{3}\right]^{+}$species, and their further testing in the solutions simulating alkaline Hanford tank supernatants is warranted.

\subsection{References}

Alberto R, R Schibli, A Egli, PA Schubiger, WA Herrmann, G Artus, U Abram, and TA Kaden. 1995. "Metal carbonyl syntheses XXII. Low pressure carbonylation of $\left[\mathrm{MOC1}_{4}\right]^{-}$and $\left[\mathrm{MO}_{4}\right]^{-}$the technetium(I) and rhenium(I) complexes $\left[\mathrm{NEt}_{4}\right]_{2}\left[\mathrm{MCl}_{3}(\mathrm{CO})_{3}\right.$." J. Organomet. Chem., 493, pp. 119-127.

Alberto R, R Schibli, A Egli, U Abram, S Abram, TA Kaden, and PA Schubiger. 1998. "Steps towards [(C5Me5)TcO3]: Novel synthesis of [(C5Me5)Tc(CO)3] from $[\{\mathrm{Tc}(\mathrm{p} 3-\mathrm{OH})(\mathrm{CO}) 3\} 4]$ and oxidation of [(C5Me5)M(CO)3] $(\mathrm{M}=\mathrm{Tc}, \mathrm{Re})$ with Br2.” Polyhedron, 17(7), pp. 11331140.

Armstrong R and H Taube. 1976. "Chemistry of trans-aquonitrosyltetraamminetechnetium(I) and related studies.” Inorg. Chem., 15, pp. 1904-1909.

Brown D, J Newman, J Thornback, and A Davison. 1987. "Structure of the tetra-n-butylammonium salt of the tetra-chloro(methanol)nitrosyltechnetium(II) anion." Acta Cryst., C43, pp. 1692-1694.

Brown D, J Newman, and J Thornback. 1988. "The structure of the tetra-phenylarsonium salt of the tri-chloro(pentane-2,4-dionato)nitrosyltechnetium(II) anion.” Acta Cryst., C44, pp. 973-975.

Cheah C, J Newman, D Nowotnik, and J Thornback. 1987. "Synthesis and Biological Studies of the [Tc99m] Tetrachloronitrosyltechnetium(II) Anion - An Alternative Low Valent Technetium Starting Material." Nucl. Med. Biol., 14, pp. 573-579. 
Cho H, WA de Jong, BK McNamara, BM Rapko, and IE Burgeson. 2004. "Temperature and Isotope Substitution Effects on the Structure and NMR Properties of the Pertechnetate Ion in Water." J. Am. Chem. Soc. 126, 11583-11588.

Cook AR, N Dimitrijevic, BW Dreyfus, D Meisel, LA Curtiss, and DM Camaioni. 2001. "Reducing Radicals in Nitrate Solutions." The NO3 2- System Revisited.” J. Phys. Chem. A. 105: 3658-3666.

Dattelbaum DM, KM Omberg, JR Schoonover, RL Martin, and TJ Meyer. 2002. "Application of Time-Resolved Infrared Spectroscopy to Electronic Structure in Metal-to-Ligand Charge-Transfer Excited States.” Inorg.Chem., 41, pp. 6071-6079.

de Vries N, J Cook, A Davison, T Nicholson, and AG Jones. 1990. "Synthesis and characterization of a technetium(III) nitrosyl compound: $\mathrm{Tc}(\mathrm{NO})(\mathrm{Cl})\left(\mathrm{SC}_{10} \mathrm{H}_{13}\right)_{3}$.” Inorg.Chem., 29, pp. 1062-1064.

Eakins J, D Humphreys, and C Mellish. 1963. "New compounds in which technetium has a low valency.” J. Chem. Soc., pp. 6012-6016.

Franklin KJ, CJL Lock, BG Sayer, and GJ Schrobilgen. 1982. "Chemical Applications of Technetium-99 NMR Spectroscopy: Preparation of Novel Technetium(Vii) Species and Their Characterization by Multinuclear NMR Spectroscopy.” J. Am. Chem. Soc., 104(20):5303-5306.

Gong CMS, WW Lukens, F Poineau, and KR Czerwinski. 2008. "Reduction of Pertechnetate by Acetohydroxamic Acid: Formation of $\left[\mathrm{Tc}^{\mathrm{II}}(\mathrm{NO})(\mathrm{AHA})_{2}\left(\mathrm{H}_{2} \mathrm{O}\right)\right]^{+}$and Implications for the UREX Process." Inorg. Chem., 47, pp. 6674-6680.

Kurz P, D Rattat, D Angst, H Schmalle, B Springler, R Alberto, H Berke, and W Beck. 2005. "The chemistry of the fac- $\left[\operatorname{Re}(\mathrm{CO})_{2}(\mathrm{NO})\right]^{2+}$ fragment in aqueous solution." Dalton T., 4, pp. 804-810.

Levitskaia TG, A Anderson, SD Chatterjee, HM Cho, BM Rapko, JM Peterson, ED Walter, and NM Washton. 2014. Speciation and Oxidative Stability of Alkaline Soluble, Non-Pertechnetate Technetium. PNNL-23654, EMSP-RPT-024, Rev. 0, Pacific Northwest National Laboratory, Richland, WA.

Linder K, A Davison, J Dewan, C Costello, and S. Maleknia. 1986. "Nitrosyl complexes of technetium: synthesis and characterization of $\left[\mathrm{TcI}(\mathrm{NO})\left(\mathrm{CNCMe}_{3}\right)_{5}\right]\left(\mathrm{PF}_{6}\right)_{2}$ and $\mathrm{Tc}(\mathrm{NO}) \mathrm{Br}_{2}\left(\mathrm{CNCMe}_{3}\right)_{3}$ and the crystal structure of $\mathrm{Tc}(\mathrm{NO}) \mathrm{Br}_{2}\left(\mathrm{CNCMe}_{3}\right)_{3}$." Inorg. Chem., 25, pp. 2085-2089.

Lu J and MJ Clarke. 1992. "Modulation of Tc-NX $(\mathrm{X}=\mathrm{O}$ or $\mathrm{S})$ bonds by $\pi$-acceptor ligands." J. Chem. Soc., Dalton T., pp. 1243-1248.

Lukens WW, DK Shuh, NC Schroeder, and KR Ashley. 2004. "Identification of the Non-Pertechnetate Species in Hanford Waste Tanks, Tc(I)-Carbonyl Complexes." Environ. Sci. Technol., 38, pp. 229-233.

Neese F. 2012. “The ORCA program system.” Wiley Interdiscip. Rev.: Comput. Mol. Sci., 2, pp. 73-78.

Nicholson T, P Muller, A Davison, and AG Jones. 2006. "The synthesis and characterization of a cationic technetium nitrosyl complex: The X-ray crystal structure of $\left[\mathrm{TcCl}(\mathrm{NO})(\mathrm{DPPE})_{2}\right]\left(\mathrm{PF}_{6}\right) \cdot \mathrm{CH}_{2} \mathrm{Cl}_{2}$." Inorg. Chim. Acta, 359, pp. 296-298. 
Pearson RG. 1963. "Hard and Soft Acids and Bases.” J. Am. Chem. Soc., 85, pp. 3533-3539.

Pearson RG. 1968a. "Hard and Soft Acids and Bases, Part I, Fundamental Principles." J. Chem. Ed., 45, pp. 581-587.

Pearson RG. 1968b. "Hard and Soft Acids and Bases, Part II, Underlying Theories." J. Chem. Ed,. 45, pp. 643-648.

Rapko BM, SA Bryan, S Chatterjee, MK Edwards, TG Levitskaia, JM Peterson, RA Peterson, and SI Sinkov. 2013. Investigations Into the Nature of Alkaline Soluble, Non-Pertechnetate Technetium. PNNL-22957, EMSP-RPT-018, Pacific Northwest National Laboratory, Richland, WA.

Rattat D, PA Schubiger, HG Berke, H Schmalle, and R Alberto. 2001. "Dicarbonyl-Nitrosyl-Complexes of Rhenium (Re) and Technetium (Tc), A Potentially New Class of Compounds for the Direct Radiolabeling of Biomolecules." Cancer. Biother. Radio., 16, pp. 339-343.

Rattat D, A Verbruggen, H Schmalle, H Berkeb, and R Alberto. 2004. "[M(CO) $\left.)_{2}(\mathrm{NO})\right]^{2+}$, a new core in bioorganometallic chemistry: model complexes of $\left[\operatorname{Re}(\mathrm{CO})_{2}(\mathrm{NO})\right]^{2+}$ and $\left[{ }^{99 \mathrm{~m}} \mathrm{Tc}(\mathrm{CO})_{2}(\mathrm{NO})\right]_{2} . "$

Tetrahedron Lett., 45, pp. 4089-4092.

Raynor JB, TJ Kemp, and AM Thyer. 1992. "Structural relationships derived from the analysis of electron spin resonance spectra of some technetium complexes." Inorg. Chim. Acta., 193, pp. 191-196.

Schäfer A, H Horn, and R Ahlrichs. 1992. "Fully optimized contracted Gaussian basis sets for atoms Li to Kr.” J. Chem. Phys. 97, pp. 2571-2577.

Schibli R, N Marti, P Maurer, B Spingler, ML Lehaire, V Gramlich, and CL Barnes. 2005. "Syntheses and Characterization of Dicarbonyl-Nitrosyl Complexes of Technetium(I) and Rhenium(I) in Aqueous Media: Spectroscopic, Structural, and DFT Analyses." Inorg. Chem., 44, pp. 683-690.

Serne RJ, BM Rapko, and IL Pegg. 2014. Technetium Inventory, Distribution, and Speciation in Hanford Tanks. PNNL-23319, Rev. 1; EMSP-RPT-022, Rev. 1, Pacific Northwest National Laboratory, Richland, WA.

Tisato F, F Refosco, and G Bandoli. 1994. "Structural survey of technetium complexes." Coord. Chem. Rev., 135/136, pp. 325-397.

Weigend F and R Ahlrichs. 2005. "Balanced basis sets of split valence, triple zeta valence and quadruple zeta valence quality for H to Rn: Design and assessment of accuracy." Phys. Chem. Chem. Phys., 7, pp. 3297-3305.

Yang Y, JX Zhang, JJ Wang, and L Zhu. 2007. "Two novel procedures of preparation for $\left[\mathrm{Tc}(\mathrm{CO})_{2}(\mathrm{NO})\right]^{2+}$ labeled by EHIDA and its biodistribution." J. Radioanal. Nucl. Ch., 273, pp. 31-36. 

PNNL-24916

EMSP-RPT-030, Rev. 0

\section{Distribution*}

U.S. Department of Energy

Office of Environmental Management

NP Machara

SP Schneider

Washington State University

TJ Martin

NA Wall

\section{Pacific Northwest National Laboratory}

SD Chatterjee

GB Hall

TG Levitskaia

RA Peterson

BM Rapko

RJ Serne

ED Walter

Information Release

(PDF)

*All distribution will be made electronically. 




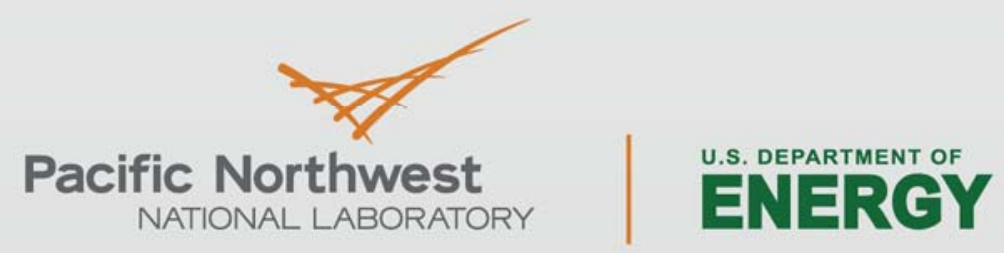

Proudly Operated by Battelle Since 1965

902 Battelle Boulevard

P.O. Box 999

Richland, WA 99352

1-888-375-PNNL (7665)

www.pnnl.gov 